\title{
How Responsive is Investment in Schooling to Changes in Redistributive Policies and in Returns?*
}

\author{
Ran Abramitzky \\ Stanford University \\ and NBER
}

\author{
Victor Lavy \\ Hebrew University, \\ University of Warwick and NBER
}

April 2012

\begin{abstract}
This paper uses an unusual pay reform to test the responsiveness of investment in schooling to changes in redistribution schemes that increase the rate of return to education. We exploit an episode where different Israeli kibbutzim shifted from equal sharing to productivity-based wages in different years and find that students in kibbutzim that reformed earlier invested more in education. This effect is stronger for males and is mainly driven by students whose parents have lower levels of education. Our findings support the prediction that education is highly responsive to changes in the redistribution policy, especially for students from weaker backgrounds.
\end{abstract}

\footnotetext{
${ }^{*}$ We thank Izi Sin, Josh Angrist, Orazio Attanasio, Sacha Becker, Ken Chay, Giacomo Degiorgi, Pascaline Dupas, Liran Einav, Erica Field, Oded Galor, David Genesove, Nora Gordon, Eric Gould, Avner Greif, Mark Harrison, Caroline Hoxby, Seema Jayachandran, Rob Jensen, Dirk Jenter, Pete Klenow, Ruth Klinov, Saul Lach, Ed Lazear, Tim Leunig, Alan Manning, Kaivan Munshi, Roy Mill, Joel Mokyr, Steve Pischke, Olmo Silva, Paul Schultz, John Van Reenen, Jonah Rockoff, Yona Rubinstein, Fabian Waldinger, and Gui Woolston, and seminar participants in Brown, Ben Guiron University, Hebrew University, Columbia, LSE, Stanford, Warwick, Yale, Vanderbilt, Simon Fraser, Higher School of Economics, and the NBER Education and Children Spring 2011 conference for most useful discussions and suggestions. We thank Roy Mill, Alex Zablotsky and Sergei Sumkin for excellent research assistance. We are grateful to Shlomo Getz for sharing his data on the pay reform, and to Avner Barzilai from the kibbutz for helping us collect the data underlying Figure 2, as well as Tables A1 and 2.
} 


\section{Introduction}

We study the effect of changing the redistributive policy on the educational choices of Israeli teenagers. In particular, we examine a unique episode where some kibbutzim (plural of kibbutz) changed their decades-long policy of setting wages independent of an individual's human capital to setting wages to reflect the market rate of return. This sharp change in the redistributive policy from equal sharing to pay-for-productivity introduced a dramatic increase in the returns to schooling for kibbutz members. We rely on this sharp change to test whether and to what extent this policy change induced high school students to invest more in their education, as reflected by their academic achievements.

This paper contributes to two strands of the literature. From a public economics perspective, this paper sheds light on the extent to which redistributive policy influences long run labor supply, as mediated through educational choices. While it is well known that changes in taxes affect labor supply decisions in the short run, ${ }^{1}$ as pointed out by Saez, Slemrod and Giertz (2009), much less is known about how such changes affect labor supply decisions in the long run, because it is difficult to identify empirically how such tax changes will affect educational choices. This paper fills this gap by studying how responsive are educational choices to tax changes.

From labor economics perspective, economic models of optimal human capital investment (Ben Porath 1967, Becker 1967) suggest that the level of investment in schooling is expected to increase in the perceived rate of return to education. The basic premise is that future labor market returns in the form of earnings are a main motivation for investment in schooling, and the higher are these market rates of return the higher is the optimal level of investment. However, despite its centrality in modern labor economics, this fundamental assumption has hardly been tested empirically, both because variation across individuals in the rate of return to schooling is rarely observed and because sharp changes in this return rarely occur. Our paper informs us about the responsiveness of investment in schooling to changes in returns, as the pay reform sharply increased the returns to schooling.

We use administrative records collected by the Israeli Ministry of Education for six consecutive cohorts (from 1995 to 2000) of $10^{\text {th }}$ grade students, following them to graduation. The data contain detailed demographic information on each student as well as his home address. We use the latter to determine who lives in a kibbutz and when a student's kibbutz implemented the pay reform. A main outcome of interest we examine is students' achievement in the matriculation exams at the end of high school. Passing all the matriculation exams successfully

\footnotetext{
${ }^{1}$ See also Chetty et al. (forthcoming) on how the effects of taxes on labor supply are shaped by interactions between adjustment costs for workers and hours of work constraints set by firms.
} 
and getting a matriculation diploma (equivalent to a baccalaureate diploma in most of the European countries) is a major milestone in education in Israel as it is the ticket to post-secondary schooling; it yields a substantial earning premium in the general Israeli labor market. Other outcomes of interest are whether the student graduated high school, the average score in the matriculation exams, and whether her diploma meets the university entrance requirements.

Our identification strategy relies on the fact that the pay reform was not implemented in all kibbutzim in the same year. We use a difference-in-differences approach, illustrated in Figure 1, comparing educational outcomes of high school students in kibbutzim that reformed early (the "treatment group") and late (the "control group"), before and after the early reforms (but before the late reforms). We show evidence that students in the treatment and control groups are nearly identical in all observable background characteristics on which we have information, such as parental schooling and number of siblings, as well as very similar in all their pre-reform schooling outcomes.

Specifically, as our first difference, we compare students in kibbutzim that reformed early (1998-2000) with students in kibbutzim that reformed late (2003-2004). As our second difference, we compare students who were affected by the early pay reforms (were in high school after the early reform but before the late reform began) with students who were unaffected by the early reforms (were in high school before the early reforms). The difference in this difference between kibbutzim that reformed early vs. late can be interpreted as the causal effect of the reform, under the assumption that in the absence of the reform, the change in achievements would not have been systematically different in treatment and control groups.

We find that students in kibbutzim that reformed early increased their investment in education as reflected by their educational outcomes. The mean score in the matriculation exam (Bagrut) increased by 3.55 points relative to a pre-reform mean of 70.6 , or by 0.17 standard deviations of the test score distribution. The matriculation rate increased by 4.9 percentage points, and the university qualified Bagrut rate increased by 6.0 percentage points, which is almost 12 percent of the pre-reform university qualified Bagrut rate in the control group. The pay reform even increased the high school completion rate by a significant 3.3 percentage points, from a baseline that was already over 95 percent for the pre-reform cohorts. To translate our coefficients into semi elasticities, ${ }^{2}$ we calculate that the pay reform increased the return to a year of schooling for the average student by about 7 percentage points. Our estimates thus imply that a 1 percentage

\footnotetext{
${ }^{2}$ We feel more comfortable to report results in terms of semi elasticities rather than elasticities because the pre-reform returns were close to zero, making an elasticity measure highly sensitive to exact pre-reform return.
} 
point increase in the returns to a year of schooling increases graduation rates by $0.43(3 / 7)$ percent, improves the proportion of students graduating with a university qualified matriculation by 1.7 percent (12/7) and improves mean exam scores by 0.51 points $(3.55 / 7)$.

Furthermore, we exploit the variation in the intensity of the pay reform and show that the effect is mainly driven by students in kibbutzim that reformed to a larger degree. Importantly, some kibbutzim introduced a full pay reform and moved directly to a pay system that reflected market forces. Other kibbutzim initially introduced only a partial pay reform that was partly based on market forces, but which also included a wide safety net for members with the lowest earnings potential. Many partially reformed kibbutzim eventually fully reformed, and many did so during our period of study. We find that the effect of the pay reform was the largest for students who lived in a fully reformed kibbutz throughout their three years of high school, even compared with students whose kibbutz fully reformed a year or two into their high school. These results further strengthen the causal interpretation of the evidence since it is difficult to imagine other plausible reasons that could explain the difference in the effect of the pay reform by its intensity.

This positive effect of the reform on education outcomes is mainly driven by students whose parents have lower levels of education. This finding rules out a possible income effect of a change in the redistributive policy, whereby we would expect more educated people who gained from the reform to respond more because they could invest more in their children's education. The difference we find likely reflects inherent differences between people from different educational background in the responsiveness to the change in the returns to schooling brought by the reforms. For example, more educated parents may be more likely to convey to their children that education is important in itself. It is also consistent with the idea that the utility is concave in income, making a future dollar increase in earnings more valuable for students who expect to end up in the low tail of the income distribution; thus students from weaker background are more likely to increase their investment in education.

Our evidence that children from low educated families respond more vigorously to the increase in the rate of return to schooling suggest a negative relationship between the return to schooling and inequality. This negative relationship is in sharp contrast to the positive association between these two variables highlighted in the literature on the rising inequality of income in the last three decades. ${ }^{3}$ Skill biased technical change, it is argued, increased the demand for high skilled workers, increasing as a result the college premium and wage inequality. In skilled biased technical change story these changes are demand driven while in our case of a decline in the

\footnotetext{
${ }^{3}$ See Autor and Katz and Kearney (2008).
} 
income tax rate the trigger is a resulting increase in the supply of skilled workers (see further discussion in the conclusions).

Furthermore, unlike other papers that find that females tend to be more responsive to changes in schooling incentives (e.g. Schultz 2004, Angrist and Lavy 2009), we find a larger effect for males. This difference likely stems from the fact that, unlike other studies, we study a pay reform that affects future earnings, not a program that directly rewards high performance in school. Females could be less responsive if, for example, they expect to be the secondary earner in their household, meaning they expect their human capital to contribute less to the overall household income. Indeed, we show using labor force surveys that females are less likely to be in the labor force and more likely to sort into low-wage occupations. This finding also contributes to our understanding of how the labor supply response to taxation differs by gender. While the literature suggests that women's labor supply is more responsive than men's to changes in income taxes (see for example, Alesina, Ichino and Karabarbounis, 2007) our finding suggests that men's investment in human capital could be more responsive than women's.

The identifying assumption in our empirical strategy is that the exact year in which a kibbutz reformed is unrelated to the potential outcomes of its high school students. We provide several reasons with supporting evidence, why we believe that this assumption holds in our case, and why the results are not due to selection or sorting that determined the decision of kibbutzim about the reform and its timing: (1) This assumption implies that older cohorts of early- and latereforming kibbutzim should have had similar high school outcomes on average, and indeed there does not appear to be any sorting on a variety of outcomes and other important background variables as we find near-perfect balancing between treatment and control on all these dimensions. (2) We find no pre-reform differences between treatment and control kibbutzim in time trends of educational outcomes. (3) We find low and identical exit rates of kibbutz families of high school students both before and after the implementation of the pay reform. (4) Placebo regressions based on several pre-treatment cohorts show zero treatment effects, evidence which strengthens our results of no treatment-control differences in pre-reform outcomes and trends. (5) When comparing kibbutzim that reformed at the same time, we find that the effect is driven mainly by kibbutzim that reformed to a larger degree, which provides additional evidence that the timing of the reform is not a source of selection that can explain our results. (6) Any selection or sorting factors at the kibbutz level should affect similarly the families of boys and girls in reformed kibbutzim, so if sorting is producing our results, we should obtain similar results for males vs. females, but we do not; a similar argument can be made with respect to the 
heterogeneous results we find with respect to high and low education families in treated kibbutzim. For these reasons, it is reasonable to interpret the estimated effects in a causal manner.

The rest of the paper is structured as follows. The next section provides a short review of the existing literature that is most closely related to our paper. Section III presents a brief background of kibbutzim and the pay reform, and of the Israeli high school system, and also describes the data. Section IV discusses the empirical framework and identification strategy. Section V presents the estimation results, section VI puts into perspective the magnitudes of the effects, and section VII concludes.

\section{Literature Review}

Despite an important body of theoretical literature, the empirical literature that tests the relationship between the rate of return to education and investment in schooling is relatively small. Freeman (1976) studied changes in college enrollments in the US and found that they were responsive to changes in rates of return to schooling. Kane (1994) finds evidence that whites' college enrollment rates in the 1980's in the US were responsive to the increase in returns to education, as measured by the ratio of college graduates' to high school graduates' mean earnings (the college premium). For blacks, however, there is little evidence of such a relationship. This conclusion is based on the trends in enrollment rates not being different by gender for blacks even though there were large gender differences in the trend in the college earnings differential. However, Kane (1994) also reports that students seem to be more responsive to increases in direct costs than they are to the present value of future earnings differentials. However, as noted by the author, the limitation of these findings is that they are primarily based on a coincidence of time series, namely the similar timing of a rise in returns to education and a rise in college entry. Therefore a causal interpretation of the association between returns and college enrollment is not possible in this case.

Several studies estimate the perceived rate of return to schooling, as distinct from the actual rate of return estimated in this paper, and some then assess its effect on schooling. Betts (1996) and Smith and Powell (1990) have attempted to estimate the perceived returns among high school and college students. The latter study finds that students accurately estimate the earnings of college educated workers; however, men on average expect their own earnings to be above the mean for such workers, a finding the authors attribute to an optimism bias in perceived ability. Dominitz and Manski (1996) approach the measurement of perceived returns directly by asking high school and college students to estimate what their future earnings would be in hypothetical situations of different levels of education. They find that men accurately estimate the earnings of 
other men with different levels of education, while women tend to overestimate the earnings of other women. Avery and Kane (2004) also ask about own expected earnings in assessing the perceived returns to college education among high school students in the Boston area. They find that students overestimate the returns to education. Jensen (2010) uses survey data from the Dominican Republic and reports the opposite findings. Specifically, students under-predict their returns to education, and students who were better informed (experimentally) of the higher estimated returns were significantly less likely to drop out of school in subsequent years. Attanasio and Kaufman (2009) analyzes the link between people's "subjective" expectations of returns to schooling and their decision to invest into schooling based on data from a household survey on Mexican junior and senior high school graduates that elicits their own and their parents' beliefs about future earnings for different scenarios of highest schooling degree. The results suggest that college attendance decisions depend on expected returns to college. Millett and Oster (2011) also demonstrate that school enrollment decisions respond to future market prospects. They find that introducing new Information Technology Enabled Services (ITES) centers in India causes a $4 \%$ to $7 \%$ increase in the number of children enrolled in primary school and suggest these impacts are due to changes in returns to schooling, and not due to income resulting from the ITES centers.

Other somewhat related research explores the relationship between the business cycle and investment in schooling. Specifically, Sakellaris and Spilimbergo (2000) focus on foreign students coming to US universities and find that for OECD countries enrollment is countercyclical, whereas it is pro-cyclical for non-OECD countries.

Our paper is also related to a literature on the achievements of high school students in kibbutzim relative to students in cities. This literature focuses on the pre-reform period. Trumper (1997) compares samples of kibbutz and city students and finds that, while in junior high school (grades 8 and 9), city students were better achievers than kibbutz students, this difference became insignificant in senior high school (grades 10 and 11). Gilboa (2004) uses data from psychometric test results during the period 1992-1996 and compares achievements of kibbutz and city children. He finds no differences in the average grade of children whose parents have more than 12 years of schooling. However, among children of less educated parents, kibbutz children had higher average grades. 


\section{Background and Data}

\section{a. The pay reform and the rate of return to schooling in kibbutzim}

\section{i. Brief description of kibbutzim and the nature of the pay reform}

Kibbutzim are voluntary communities that have provided their members with a high degree of income equality for almost a century. ${ }^{4}$ Traditionally, all kibbutzim were based on full income sharing between members. Specifically, each member of a kibbutz was paid an equal wage, regardless of her contribution to the community. Kibbutz members who worked outside their kibbutz brought their salaries in, and these were split equally among members. This meant that monetary returns to ability and effort were close to zero. Specifically, there were no earningsrelated returns to schooling in the kibbutz, as members earned the same regardless of their education levels. ${ }^{5}$

The episode that we study is a unique pay reform that kibbutzim in Israel adopted beginning in 1998. During the following years, many kibbutzim shifted from equal sharing by introducing compensation schemes based on members' productivity, which created a link between productivity and earnings in kibbutzim for the first time. These pay reforms were a response to changing external pressures and circumstances facing kibbutzim. Some contributing factors were a decline in world prices of agricultural goods, bad financial management, and a high-tech boom during the mid-1990s, which increased members' outside options considerably. But perhaps the biggest problem was that many kibbutzim had borrowed heavily in the 1980s, both to expand their housing stock and to expand their industry. In the early 1980s, it was easy and cheap for kibbutzim to borrow money because inflation in Israel was very high and loans were often not indexed to inflation. However, the Israeli government eventually decided to take action to halt the inflation and, as part of the stabilization program, raised interest rates dramatically. Kibbutzim, like many other businesses in Israel, found themselves with huge debts they could not repay. Eventually, some of the loans were erased and others were rescheduled, but living standards in many kibbutzim still fell substantially, many members left during the late 1980s and early 1990s, and talk about a major reform of kibbutz life began.

\footnotetext{
${ }^{4}$ For a history of kibbutzim, see Near $(1992,1997)$. For an overview of the economics of kibbutzim, see Abramitzky (2011).

${ }^{5}$ Kibbutz scholars and observers have often felt, as predicted by economic theory, that under the traditional kibbutz system, kibbutz-raised children often lacked ambition and a sense of personal achievement. Bettelheim (1969) concluded that "they will not be leaders or philosophers, will not achieve anything in science or art." This quote was also cited in Gavron (2000).
} 
In reformed kibbutzim, members' wages reflected market wages so that members were allowed to keep a substantial fraction of their earnings for themselves. For members who worked outside their kibbutzim (about a fourth of all members), market wages were the wages they received from their employers (prior to the reform, these wages were brought by members to their kibbutz and were split equally among all members). For members who worked inside, market wages were based on the wages of non-kibbutz workers of similar occupation, education, skills, and experience. A kibbutz 'tax' was deducted from members' gross wages to guarantee older members and very low wage earners in the kibbutz a safety net (i.e. a minimum wage). We note that throughout the period we study, students made free educational choices.

\section{ii. How the reform changed the return to schooling}

The pay reform was essentially a sharp decrease in the income tax rate. Before the reform, income in kibbutzim was $100 \%$ taxed. Post reform, the tax rates in kibbutzim became more similar to the Israeli tax rates. Specifically, kibbutz members faced a progressive tax system, with marginal tax rates ranging from 20 to $50 \%$.

To gain a sense of how big the reform was in terms of an increase in the return to education, note that pre-reform the monetary return to education was zero and post reform the return to education became similar to the rest of Israel, which is estimated by various studies at about $8 \%$ per year of schooling. In actuality, the reform likely increased the return to education by less than $8 \%$ per year for several reasons. First, monetary rewards are not the only reason people acquire education. ${ }^{6}$ Indeed, members of kibbutzim have never been uneducated even before the pay reform, despite the absence of monetary returns to schooling. Non-monetary incentives such as prestige and care about the collective had always played a role in the prereform period. It could also be that before the reform, factors such as peer pressure and collective bargaining affected members' education decisions. We note that such factors that increase the pre-reform return to education are inherent to highly redistributive policies. We also note that they cause us to overstate the size of the increase in return to schooling, and thus underestimate the estimated elasticities with respect to changes in return to schooling.

Second, the exit option meant that the return to education was higher than zero pre reform, and some members might have acquired education to improve their wages upon exit. ${ }^{7}$ If a

\footnotetext{
${ }^{6}$ See Oreopoulus and Salvanes (2009) for a recent paper that makes this point convincingly.

${ }^{7}$ As noted, a kibbutz-born individual could always choose to leave her kibbutz and earn the market rate of return on her education outside. At the same time, a range of mechanisms was in place to limit the attractiveness of this option (for example, bequests were not allowed, and members could not take their share of the assets of the kibbutz with them). Note that Israel is a small country, meaning the outside
} 
high school student knew for sure that he was going to leave in the future, his perceived return to schooling was high even pre reform, and the pay reform did not change his perceived return to schooling. On the other hand, a high school student who planned on staying faced no monetary returns to schooling and the full pay reform increased his return by 8 percentage points. For an average high school student who had not yet decided whether to stay, the reform increased the perceived returns by less than the full $8 \%$, or about $6.4 \%{ }^{8}$ Third, for kibbutzim that only reformed partially, the post reform returns are smaller, so that their pay reform increased the returns by a lower amount.

To illustrate how the reform increased returns to schooling, we collected data on the earnings and education of all working members in one particular kibbutz that is currently reforming its pay system from equal sharing to a full pay reform. Figure 2 (and the underlying Online Appendix Table A1) illustrates that while before the reform members of all education levels earned the same wage, post reform more educated members earned higher wages in this kibbutz. In addition, we collected data on post reform wages of all working members in another fully reformed kibbutz (one of our treatment kibbutzim). Pooling observations from these two fully reformed kibbutzim, Table 1 illustrates the large returns to schooling after the pay reform. Specifically, we run a regression of $\ln$ (wages) post reform on education level, with and without controlling for a member's age and age squared. A bachelor degree is associated with $35 \%$ increase in wage relative to high school education $(\exp (0.3)-1)$. A master degree is associated with a $57 \%$ premium, and doctoral degree with a $88 \%$ premium. Stating these different degrees in terms of years of schooling, we find that an extra year of schooling is associated with $8 \%$ higher wages, which is the same as the returns outside of kibbutzim. This finding is consistent with Klinov and Palgi (2006), who found similar returns to education for kibbutz members and city residents using survey data from 2004 (Labor Force Survey) and 2005 (kibbutzim survey ${ }^{9}$ ).

market return to education was the same for members of all kibbutzim, specifically both in kibbutzim that reformed early and later. Moreover, we show in a later section that exit rates during the period we study were relatively low and nearly identical in kibbutzim that reformed early and late.

${ }^{8}$ To gain a sense of the increase in return for such an average student, we note that in the decade prior to the reform, about $20 \%$ of members left their kibbutz, implying that the perceived return for such a student pre reform was $1.6 \%$ so that the reform increased their perceived returns by $6.4 \%$ points. To see this, assume a high school student that plan to exit the kibbutz in the future with probability $20 \%$. The prereform returns for such student is $0.2 *$ (ReturnOutside) $+0.8 *$ (ReturnInside) $=0.2$ (ReturnOutside) $+0.8 * 0=$ $0.2 * 8 \%=1.6 \%$. That is, the pay reform increases the return to schooling for such student by $6.4 \%$.

${ }^{9}$ This is a Survey of Public Opinion in kibbutzim to estimate Mincerian wage equations for a sample of wage earners in Israeli cities and for a sample of kibbutz members. The survey was conducted in 2005 by Michal Palgi and Eliat Orchan of the Institute for Research of the Kibbutz at Haifa University. 


\section{iii. Why compare kibbutzim that reformed in different years}

Kibbutzim that even today are based on equal sharing and never reformed differ from those that did in that they had very different experiences in the decade leading to the reform period (Abramitzky 2008). Specifically, kibbutzim that reformed experienced a deeper financial crisis and higher exit rates in the decade leading to the reform. Kibbutzim that did not reform are therefore not a good comparison group for those that did.

Kibbutzim that implemented the same pay reform a few years apart from each other are more likely similar to each other. While it is difficult to know exactly why some kibbutzim reformed in 1998 and others in 2003, this likely reflects differences in the degree of internal opposition to the reform by the objecting minority (often older members) in the kibbutz, and is unlikely to be related to the outcomes we study in this paper. ${ }^{10}$ Indeed, we later show that students in kibbutzim that reformed earlier were practically indistinguishable from those in kibbutzim that reformed later in both their background characteristics and their pre-reform educational outcomes.

\section{iv. How salient was the reform}

Evidence suggests the move from equal sharing to differential pay signaled strongly to young adults in the kibbutzim an increase in the financial rewards to human capital. First, this pay reform was a dramatic change in the returns to skill. Whereas before the reform wages were equal for all members of a kibbutz, the reform introduced huge productivity-related wage differences within a kibbutz for the first time. This increase in the return to skills was noticeable within a family, as students' parents experienced a decrease or increase in their earnings depending on their skills (Figure 2 and Appendix Table A1 illustrate this point). This change was also noticeable in kibbutzim as a whole. A survey of 3000 kibbutz members conducted by Pilat institute in 2004 reveals huge wage differences by occupation and education. For example, a director of a kibbutz sector (e.g. agriculture sector or industry sector) started to earn close to

${ }^{10}$ Since the pay reform was such a fundamental change in the key defining principle of kibbutzim, implementing it in a kibbutz required the overwhelming support of a large majority of the kibbutz's members. This was not an easy process, because such a reform was against the original ideology of the kibbutz and many members, especially the older cohorts, had lived their entire lives under full equal sharing and strenuously resisted the change. Older members were also potentially the biggest losers from linking salaries to productivity because they no longer worked, but had supported the earlier generation by working during the previous decades of equal sharing. Some members even took their kibbutz to court, claiming that a shift from equal sharing meant reneging on the original contract they had entered with their kibbutzim years earlier. Younger members were the ones typically leading the reform. They claimed that times had changed and a reform that linked salaries to productivity was necessary for the kibbutzim to remain viable communities. The eventual reforms almost always protected older members who didn't work by providing them with a safety net. 
30,000 New Israeli Shekels (NIS) (about $\$ 8000$ per month), and members in leading positions such as the main secretary (chairman) and the treasurer of the kibbutz earned over 15,000 NIS (about $\$ 4000$ ). Over $80 \%$ of members holding such positions have academic degrees. In contrast, a member working as a menial laborer in the kitchen or in the laundry, none of whom had a post high school academic education, earned less than 4,000 NIS (about \$1000). A more recent survey in 2009 that included 180 kibbutzim that reformed their pay structure reveals large pay gaps within kibbutzim. The survey looked only within kibbutzim; it provided data on the monthly wages of 120 different occupations. The highest gross monthly income recorded in the survey was 17,500 NIS $(\$ 4,600)$ and the lowest 4,100 NIS $(\$ 1,080)$. This range suggests large income inequality, which is most likely much higher once the wages of the members employed outside the kibbutz are taken into account. ${ }^{11}$

Second, the pay reform was highly noticeable by members. The pay reforms in kibbutzim have been the most discussed topic in kibbutzim since the reforms started. The new productivitybased sharing rules were hotly debated and voted on by members in kibbutzim. Booklets elaborating on the reforms were distributed to all members. There were even some cases of kibbutz members suing their kibbutz because of the pay reform. The pay reform also received a lot of attention in the media both in Israel and abroad. Naturally, high school students in kibbutzim observed the heated discussions over the pay reform and saw their parents' wages increase or decrease substantially depending on their education and skills. Thus they must have been aware both that their kibbutz had instituted a pay reform and of its practical implications.

We note that even though people in kibbutzim grew up in communities where the link between schooling and earnings was essentially non-existent, they were in a very good position to understand their post-reform rates of return to schooling. Kibbutzim are typically located close to cities, kibbutz-born children interact with non-members in their high schools, they very often have family outside of the kibbutz, and in general, unlike American communes, kibbutzim are not isolated from the Israeli society as a whole and they are well aware of their outside options (Abramitzky 2011). Moreover, with the implementation of the reforms, kibbutz members received detailed information about the new sharing rule and how earnings were now going to be linked to productivity and reflect market forces.

Finally, we note that no kibbutz that reformed moved back to equal sharing. Looking ahead, kibbutzim that reformed are very unlikely to ever go back to equal sharing, meaning high school students were reacting to a permanent change in their perceived returns schooling.

\footnotetext{
11 This information is provided in the daily newspaper Haaretz article in 17/09/2009. [www.haaretz.co.il/hasite/objects/pages/PrintArticle.jhtml?itemNo=1115205]
} 


\section{v. Did late reformers observe early reformers and anticipate they would reform too}

While the pay reform was implemented starting at a particular date and created a sharp change in the wage structure, we cannot rule out that members in kibbutzim that reformed later observed the reforms in other kibbutzim, and anticipated that at some later date their kibbutz would reform too. However, three relevant things are worth noting. First, conceptually, we note that even if anticipation effects were present, such effects make it more difficult for us to find an impact of the reform, because it would imply that students in the control group too perceived some possible increase in the returns to education and increased their investment in schooling accordingly. Second, this is one reason we choose as a control group kibbutzim that reformed at least four years after the treatment kibbutzim reformed, making such anticipation effects less likely and less prominent if they exist. Third, empirically, we do not find evidence for such an effect, in the sense that educational outcomes in control kibbutzim are similar for the earlier and later cohorts.

\section{b. The Israeli high school system}

Israeli high school students are enrolled either in an academic track leading to a matriculation certificate (Bagrut) or in an alternative track leading only to a high school diploma. The Bagrut is completed by passing a series of national exams in core and elective subjects taken by the students between $10^{\text {th }}$ and $12^{\text {th }}$ grade. Thus, Bagrut certificates are typically obtained at the end of senior year (twelfth grade) or later.

Students choose to be tested at various proficiency levels, with each test awarding one to five credit units per subject, depending on difficulty. Some subjects are mandatory and many must be taken for at least three units. Advanced level subjects are those subjects taken at a level of four or five credit units. A minimum of 20 credit units is required to qualify for a Bagrut certificate, though some university study programs require more, and students must also satisfy distribution requirements. About 52 percent of all high school seniors received a matriculation certificate in the 1999 and 2000 cohorts (Israel Ministry of Education 2001). Roughly 60 percent of those who took at least one Bagrut subject test ended up receiving a Bagrut certificate.

The matriculation certificate is a prerequisite for university admission and receiving it is one of the most economically important educational milestones. Similar high school matriculation exams are found in many countries and in some states in the United States. Examples include the French Baccalaureate, the German Certificate of Maturity, the Italian Diploma di Maturità, and the New York State Regents examinations. 
Although the Bagrut is an Israeli institution, it can be understood in the American vernacular as a "college-bound" indicator. Most of the Israeli students who fail to complete a Bagrut still finish their secondary schooling. Nevertheless, postsecondary schooling options for high school graduates without a Bagrut are limited ${ }^{12}$; very few will obtain further schooling. Even institutions that are not otherwise very selective, such as teachers' colleges and two-year professional programs for nursing, optometry, and computer programming, favor applicants with a Bagrut certificate. Consistent with this, regression evidence from the Israeli census suggests that the economic returns to a Bagrut are high. While there is no experimental evidence for the earnings consequences of a Bagrut certificate, Abramitzky (2009) shows that having at least a high school diploma (which is achieved by completing 12 years of schooling without receiving a Bagrut certificate) is associated with $36 \%$ higher earnings. ${ }^{13}$

We note that kibbutz children typically go to regional high schools (mostly located outside of kibbutzim), where they are mixed with children from other kibbutzim and from villages not based on equality (moshavim).

\section{c. Data}

The empirical analysis is based on a sample that includes high school students who live in kibbutzim at the start of $10^{\text {th }}$ grade, the information on whom is drawn from several administrative data files obtained from the Ministry of Education in Israel. We obtained administrative records collected by the Israeli Ministry of Education for six consecutive cohorts (from 1995 to 2000) of $10^{\text {th }}$ grade students. The data are based on annual reports submitted by school authorities to the Ministry of Education at the beginning of the school year. Each record contains an individual identifier, a school and class identifier, and detailed demographic information on the student: date of birth, gender, parental education, number of siblings, year of immigration (where relevant), ethnicity and, importantly, the student's home address, which allow us to determine who lives in a kibbutz.

\footnotetext{
${ }^{12}$ In the US context, Hoxby (2000) shows that people who invest in education at a more selective college earn back their investment several times over during their career. Dale and Krueger (2001) find that students who attended more selective colleges do not earn more than other students. However, the average tuition charged by the school is significantly related to the students' subsequent earnings. They also find a substantial internal rate of return from attending a more costly college and that the payoff to attending an elite college appears to be greater for students from more disadvantaged family backgrounds.

${ }^{13}$ In another context, a recent quasi-experimental study of exit exams in Texas suggests that those who pass these exams go on to get more postsecondary schooling than they otherwise would have (Francisco Martorell, 2005).
} 
We also use the home addresses of students to identify which kibbutz they live in, which allows us to link these student-level data with additional data collected by the Institute for Research of the Kibbutz and the Cooperative Idea (Getz 1998-2004) on the date at which each kibbutz reformed. We can thus classify students as belonging to kibbutzim that reformed early, or kibbutzim that reformed late, and by the degree of their kibbutz's reform. We use $10^{\text {th }}$ grade to define the base population because it is the first year of high school and the last year of compulsory schooling. Therefore, for every $10^{\text {th }}$ grade cohort at the year of the reform or following it, any change in enrollment or outcomes should be treated as endogenous.

We link the students' files with additional administrative records on schooling outcomes. We focus on the following matriculation outcomes that are available for all the years: whether the student graduated high school, whether the student received a matriculation certificate, whether the student received a matriculation certificate that meets university entrance requirements ${ }^{14}$, and the average score in the matriculation exams. Roughly, 6 percent of the students in the sample did not take the matriculation exams. These students get zero values in the average score. The other three matriculation outcomes that we use, matriculation status, matriculation status that meets university entrance requirements, and the high school completion indicator, do not require such imputation; a zero value that students get for these other outcomes is real and not an imputed measure of their achievements. We note that these outcomes allow us not only to examine whether students graduated, but also whether they increased their effort during high school, as reflected in their exam scores and matriculation status.

\section{Identification Strategy and Estimation}

In order to estimate the causal effect of the pay reform on human capital investment, we take advantage of the different timing of the reforms in different kibbutzim to construct an appropriate control group. We use a difference-in-differences approach comparing educational outcomes of high school students in kibbutzim that reformed early (treatment group) vs. late (control group), before and after the early reforms (but before the late reforms). ${ }^{15}$ Specifically, as our first difference, we compare students in kibbutzim that reformed early (1998-2000) as the "treatment group", with students in kibbutzim that reformed late (2003-2004) as the "control group". As our second difference, we compare students who were in high school when the early reform started but before the late reform began $\left(10^{\text {th }}\right.$ grade students in 1999 and 2000), with those

\footnotetext{
${ }^{14}$ A matriculation certificate that meets university entrance requirement is one that contains at least 4 credits in English and another subject at a level of 4 or 5 credits.

${ }^{15}$ We note that we don't have data for the post 2000 period. Such data could have allowed us to test whether students in kibbutzim that reformed later improved their schooling outcomes once they reformed.
} 
who were in high school before the early reforms ( $10^{\text {th }}$ grade students in 1995 and 1996). Figure 1 illustrates our identification strategy, and the time line of the early and late reforms, and of the affected and unaffected cohorts. In section V.B. we take a more continuous treatment approach by exploiting the time-varying "intensity" of the reform.

The identifying assumption in this strategy is that the exact timing of the reform is unrelated to potential outcomes of high school students. This assumption implies that older cohorts of early and late reformed kibbutzim should have had similar high school outcomes on average. Specifically, since kibbutzim started to reform their pay systems in 1998, all children who graduated from high school in 1997 or before could not have been affected by the reforms because they left high school before the pay reforms began. For younger children, the exposure is an increasing function of their date of birth. Hence, the effect of the pay reform should be close to 0 for cohorts of children who graduated in 1998 and increasing for younger cohorts. Therefore, the basic idea behind the identification strategy is to compare the difference in high school outcomes between potentially affected and unaffected cohorts in a kibbutz that reformed early and the respective difference in a kibbutz that reformed late. The difference in these differences can be interpreted as the causal effect of the reform, under the assumption that in the absence of the reform, the increase in achievements would not have been systematically different in students from early- and late-reforming kibbutzim.

In the next section we provide two related pieces of evidence in support of this assumption. First, we show that students in the treatment and control groups are practically indistinguishable in terms of their mean background characteristics. Very important in this regard is the similarity in the level of education of children's parents, which implies that the students in kibbutzim that reformed early vs. later were similar in their academic potential. Similarly, we show that students in the two groups are similar in their pre-reform mean schooling outcomes. This evidence implies that the first difference is close to zero. Second, we show that the treatment and control kibbutzim were on the same time trend of educational matriculation outcomes between 1992 (the first year with available Bagrut data) and 1998, when the first wave of reforms started.

We next discuss the estimation framework. Consider first the difference between the mean matriculation outcomes of a young cohort exposed to the reform and that of an older cohort not exposed to the reform. If the pay reform led to an increase in high school achievements, the difference between young and old cohorts in the affected kibbutzim relative to non-affected kibbutzim can be modeled as in the following simple difference-in-differences regression: 
$Y_{i k c}=\alpha_{c}+\beta_{1}\left(\right.$ EarlyReform $\left._{k}\right)+\beta_{2}\left(\right.$ AffectedCohort $_{c}$ EarlyReform $\left._{k}\right)+\varepsilon_{i k c}$

where $Y_{i k c}$ is the achievement outcome of student $i$ in kibbutz $k$ in cohort $c, \alpha_{c}$ are cohort dummies (for students starting high school in 1995, 1996, 1999 and 2000), (EarlyReform ${ }_{k}$ ) denotes whether the student belonged to a kibbutz that implemented the reform early, and (AffectedCohort EarlyReform $_{k}$ ) is the interaction of interest, namely whether the student belonged to the affected (young) cohort and lived in a kibbutz that reformed early. Standard errors are adjusted for clustering at the kibbutz level.

This simple difference-in-difference regression excludes important controls so in addition to the simple difference-in-differences regressions, we also run "controlled" specifications where we include kibbutz fixed effects, cohort fixed effects, and a vector of the student's background characteristics. We therefore estimate the following model:

$Y_{i k c}=\gamma_{k}+\alpha_{c}+\beta_{1}\left(\right.$ AffectedCohort $_{c}$ EarlyReform $\left._{k}\right)+\beta_{2} X_{i k c}+\varepsilon_{i k c}$

where $\gamma_{k}$ are kibbutz fixed effects, $X_{i k c}$ are student $i$ 's characteristics: gender, father's and mother's education, number of siblings, a set of ethnic dummies (originate from Africa/Asia, Europe/America, the former Soviet Union (FSU), Ethiopia and other countries), and the rest of the variables are as in equation (1). Note that once we include kibbutz fixed effects in the model, we have to drop the (EarlyReform ${ }_{k}$ ) term. We note that kibbutz fixed effects provide an alternative to kibbutz-level clustering. By absorbing the kibbutz-level variation in the outcome variable, they may lead to a gain in precision; clustering standard errors makes very little difference.

We note further that when comparing treated and control students, the kibbutz fixed effects essentially also capture school fixed effects because almost all students from the same kibbutz attend the same high school. We thus practically not only compare affected and unaffected students within the same kibbutz, but also within the same school.

As mentioned before, kibbutz children typically go to high schools located outside of kibbutzim, together with children from other kibbutzim and from villages not based on equality. This means that the quality of high schools kibbutz children attend is exogenous to the kibbutz. That is, the effects we document are due to the behavioral responses of students rather than changes in the quality of the educational system. Specifically, changes in school or teachers' quality or salaries could not explain our results because the 
treated children were a minority in the school they attended and that most of the teachers in these schools are not members of reformed kibbutzim.

An implication of the identification assumption can be tested because in none of the kibbutzim were individuals aged 18 or older in 1999-2000 exposed to the reform. The increase in high school matriculation achievements between cohorts in this age group should not differ systematically across kibbutzim that adopted the reforms earlier and those that adopted them later. We explore this control experiment and contrast the outcomes of two pre-reform cohorts, the 10th graders in 1995 and 1996 against the 10th graders in 1997. These are the three cohorts that started high school in the three years that preceded the first round of the pay reform. For our identification strategy to be convincing these difference-in-differences estimates should be close to zero.

\section{a. Are the control and treatment groups observationally equivalent?}

In this subsection we test directly whether the students in the treatment and control groups are statistically indistinguishable in terms of their observed characteristics. To address this issue, we check whether the treatment status (early reformed kibbutzim) is correlated with students' background variables like parental education, family size, and proportion of new immigrants. We perform these tests for two pre-reform cohorts (10th graders in 1995 and 1996), both separately and jointly, and for the post-treatment cohort of 10th graders in 1999 and 2000. For the pre-treatment cohorts we also check whether their academic high school matriculation outcomes are similar.

Table 2 presents the sample of kibbutzim and students by year of reform and by cohort. In the period 1998-2000, 74 kibbutzim reformed while 33 reformed in the period 2003-2004. The sample of students includes the cohorts of $10^{\text {th }}$ graders in 1995-1996 as pre treatment and of 1999-2000 as post treatment. The pre-treatment sample includes 1,701 students while the posttreatment sample includes 1,648 students. We have also experimented with a larger control group by including in it 13 kibbutzim that reformed in 2005 , but the results were unchanged and we therefore do not report them here.

Panel A of Table 3 provides evidence on the balancing tests and presents the mean student characteristics for each cohort by treatment status. In columns 1-3, we present the means for the 1995-1996 pre-reform cohorts and in columns 4-6 the means for the 1999-2000 post- 
reform cohorts. ${ }^{16}$ The treatment and control sample means for the pre-reform and post-reform cohorts are presented in columns 1-2 and columns 4-5 respectively. The within-cohort treatmentcontrol differences are presented in columns 3 and 6 , using the following balancing regressions:

$$
X_{i k}=\alpha+\beta\left(\text { EarlyReform }_{k}\right)+u_{i k}
$$

and:

$$
Y_{i k}=\alpha+\beta\left(\text { EarlyReform }_{k}\right)+u_{i k}
$$

where $\left(\right.$ EarlyReform $\left._{k}\right)$ again denotes whether the student belonged to a kibbutz that implemented the reform early. Standard errors are adjusted for clustering at the kibbutz level. Below we also discuss comparisons across cohorts within treatment and control groups.

Table 3 shows that student background characteristics are very similar in the treatment and control groups, both for pre and post cohorts. For example, focusing first on the pre-reform cohorts, we see that levels of parental education are very similar in control and treatment, with just over 13 years of schooling for both mother and father. The differences in parental education presented in column 3 are -0.292 (s.e. 0.174) for mother's years of schooling and -0.328 (s.e. 0.264 ) for father's years of schooling. The two respective differences for the post reform cohorts are -0.140 (s.e. 0.229 ) and -0.523 (s.e. 0.419). Note that these differences are not statistically different from zero and equally importantly they are very small relative to the respective means. The similar levels of parental education in the treatment and control groups suggest that students in the two groups had similar academic potential, both before and after the pay reform.

Similarly small and non-significant differences are also seen in all the other background characteristics. Out of the 16 estimated differences in background characteristics, the only one that is significant (at the $10 \%$ level of significance) is the difference in proportion of students of European/American ethnic origin in the post-reform sample. Note this lone significant controltreatment difference is unlikely to reflect a consistent pattern because statistically we expect one significant difference at the $10 \%$ level even in the absence of a true difference between the samples, and additionally the sign of this difference is positive while the respective difference for the pre-reform cohort is negative. We therefore view the results presented in Table 3 as an indication of good balancing, meaning that, within cohorts, the treatment and control group are indistinguishable in their observables. At the same time, we run specifications as described in equation (2), which control for these observable characteristics.

\footnotetext{
${ }^{16}$ In Table 3, we used the 1995 and 1996 cohorts together as the pre-treatment baseline but balancing tests based on each of these cohorts separately are not different from when pooling them in one sample.
} 
The above close similarity in background characteristics is also reflected in similarly small and insignificant differences in mean outcomes of the control and treatment groups in 1995/1996, presented in Panel B of Table 3. Recall that these means are pre-reform outcomes and therefore they imply an equal baseline for both groups. For example, the mean high school completion rate in $1995 / 96$ is $95.1 \%$ in the treatment group and $96.7 \%$ in the control group, and the difference between the two is 1.6 percentage points and not statistically different from zero (s.e. 1.1\%). The mean Bagrut (Israeli matriculation exam) completion rates are 54.9 and 56.9 and in the control group and treatment group, respectively, and the small difference (2.0) is again not significant (s.e. 3.6). A similar pattern exists for the other outcomes. These unconditional simple mean differences being close to zero is a good indication of a compelling natural experiment.

Table 3 also allows us to compare the cohorts within the control and treatment groups over time. The most notable change is in parental schooling, which is higher for the 1999/2000 cohort. For example, mean father's years of schooling increased in the control group from 13.6 in $1995 / 1996$ to 14.1 in $1999 / 2000$. Similarly, mother's years of schooling in the control group increased by about 0.4 , from 13.7 percent to 14.1 percent. However, the treatment-control differences remain balanced because equal changes occurred in both groups. It is also worth noting that the magnitude of the changes is small relative to the magnitude of the independent variable. In any case, in the outcome regressions we include specifications that control for the student background covariates (to allow a reduction in the variance of the error term), and we also include kibbutz fixed effects.

\section{b. Did the control and treatment kibbutzim experience different exit rates?}

High exit rates during high school that are differential between treatment and control kibbutzim could be a threat to identification if, for example, students who leave suffer academically because they need to adjust to their new high school, or if their parents moved to allow them to attend a different school. ${ }^{17} \mathrm{We}$ address this concern by checking whether the likelihood that a student leaves a kibbutz (by moving to a non-kibbutz community) is associated with the timing of the reform in his kibbutz. We identify students who exit using changes in their home address over time. We define a student as exiting if he lived in his kibbutz at the start of the

\footnotetext{
${ }^{17}$ We note that exit is not necessarily a threat for identification, even if the reform changed the probability of exit from the kibbutz. To see this, recall that post reform (in a fully reformed kibbutz) the return to schooling facing a kibbutz member is the same (8\%) regardless of whether the student plans to stay or leave (because returns inside and outside the kibbutz become the same). Thus, even if the reform changed the probability that a student will exit the kibbutz in the future, this will not bias the coefficients because the change in return to schooling is the same regardless of whether the student is more or less likely to exit post reform.
} 
$10^{\text {th }}$ grade and lived outside it at the end of the $12^{\text {th }}$ grade. $E_{i k}$ is therefore an indicator that is equal to 1 if a student left the kibbutz before completing $12^{\text {th }}$ grade, and zero otherwise, and we use it as the dependent variable in following balancing equation:

$E_{i k}=\alpha+\beta\left(\right.$ EarlyReform $\left._{k}\right)+u_{i k}$

We estimate this equation for three different samples, two pre-treatment (1995-96 and 1997-98) and one post treatment sample (1999-2000). Standard errors are clustered at the kibbutz level.

Table 4 shows that the likelihood that a student leaves his kibbutz is relatively low and unrelated to the implementation of the pay reform. The exit rate from kibbutzim of the cohort of $10^{\text {th }}$ graders in 1994/5-95/6 was 4.2 percent in the control group and 5.6 percent in the treatment group. The difference between these two rates is 0.015 (s.e. 0.016). We note that the same patterns remain for the post-reform cohort of $10^{\text {th }}$ graders in 1999-2000: the respective exit rates were 3.8 and 5.2 percent and the difference is 0.014 (s.e. 0.011). Clearly, the difference in the differences is zero. Exit rates also remained the same over time in both the treatment and control groups. In the control group the exit rates declined from 4.2 in 1995-1996 to 3.8 in 1999-2000, practically no change. In the treatment group the exit rates declined from 5.6 in the pre-reform periods to 5.2 in 1999-2000 post reform years. These results show that the small and insignificant control-treatment differences within each period were paralleled by constancy in the exit rate in each of the two groups. The similarity in exit rates between treatment and control groups and over time within these groups suggests no association between the timing of the reform and the level and changes in the exit rates from early- and late-reforming kibbutzim. This suggests that the likelihood that a student leaves his/her kibbutz is unrelated to the implementation of the pay reform. ${ }^{18}$

The low exit rates of parents in our sample are consistent with Abramitzky (2005, pp. 6162 ), which shows that members who leave their kibbutz are typically in the age range of 20-40 and very few members leave the kibbutz after the age of 45 (which is the average age of parents of students in our sample). The "brain drain" found in Abramitzky $(2005,2009)$ is mostly driven by individuals of younger ages than parents in our sample. As in Abramitzky (2005, 2009), we also find (results not shown) that high-educated parents are more likely to leave than loweducation parents, but there are no treatment-control differences in this pattern and exit rates for

\footnotetext{
${ }^{18}$ We note that students who exit are still included in the sample because excluding them would imply a sample selection criterion based on an endogenous variable. We also compared the family characteristics (parental education, family size and ethnic origin) of kibbutz leavers in our sample and found that they are not different in treatment and control kibbutzim. These results are available from the authors.
} 
both groups are relatively small. We also find no evidence for parents switching their children to different schools in response to the reform.

\section{c. Did the control and treatment kibbutzim experience different pre-reform time trends?}

We use pre-reform data on the kibbutz mean matriculation rate and Bagrut mean test score (two representative outcomes; the evidence for the other outcomes is identical) from 1993 to 1998 to estimate differential time trends for treatment and control kibbutzim. The unit of observation in this analysis is a kibbutz-year. We employ two methods for this estimation. First, we estimate the following constant linear time trend model while allowing for an interaction of the constant linear trend with the treatment indicator:

$Y_{k c}=\gamma_{k}+\beta_{1} c+\beta_{2}\left(c \times\right.$ EarlyReform $\left._{k}\right)+v_{k c}$

where $c$ is the cohort (year the student started high school) so that $\beta_{1}$ measures the constant linear time trend and $\beta_{2}$ measures the mean treatment-control difference in this time trend. We also include specifications with the main effect for the treatment group (the indicator of early reform) instead of kibbutz fixed effects. Second, we estimate a model where we replace the linear time trend variable with a series of year dummies and include in the regression an interaction of each of these cohort dummies with the treatment indicator. Specifically, we estimate the following equation:

$Y_{k c}=\gamma_{k}+\alpha_{c}+\beta_{c}\left(\right.$ EarlyReform $\left._{k}\right)+v_{k c}$

For each cohort $c, \beta_{c}$ measures the mean treatment-control difference in the outcome. The estimates from both models suggest that there is a time trend in the educational outcomes used, but this trend is identical for treatment and control kibbutzim. These results are presented in Table 5. Panel A presents the estimates of the linear trend model. The mean trend is an annual increase of 0.025 in the matriculation rate and a 1.225 points annual increase in test scores. The estimated coefficient on the interaction of this trend with the treatment indicator is practically zero in both cases. Moreover, the estimated coefficient of the treatment indicator main effect is zero in both cases, again confirming the balancing tests' results on pre-reform outcomes presented in Table 3 .

Panel B presents the estimates of the year dummies model. The evidence presented in panel B is fully consistent with the linear trend model. The interaction terms of the treatment indicator with the year dummies are all small and not significantly different from zero; we also note that some are positive and others are negative, lacking any consistent pattern. This conclusion is supported by the fact that we cannot reject the hypothesis that all the interaction 
terms are jointly equal to zero. These $\mathrm{F}$ tests are reported in the bottom row of the table for the regressions reported in column 2 and column 4 . We are therefore confident that there were no pre-1998 existing differential time trends in early- and late-reforming kibbutzim that could confound the estimated treatment effects that we present below.

\section{The Effect of the Reform on Educational Outcomes}

\section{a. Basic Results}

Before we present the main results by the intensity of the reforms in the next section, this section shows the basic results without taking this intensity into account. Panel A, first row, of Table 6 reports simple difference in differences estimates with no additional controls and in the second row we present the difference in differences estimates which are based on regressions that also include individual characteristics and kibbutz fixed effects. Each cell in the table shows the estimated coefficient on the affected cohort in treated kibbutzim. These results show a positive coefficient of interest for all schooling outcomes. That is, relative to control kibbutzim, there was a larger improvement in schooling outcomes following the reform in treated kibbutzim. Three things are worth noting before we discuss the results further. First, the pay reform increased the high school completion rate, despite the fact that this rate was already over 95 percent for the prereform cohorts in the sample, implying limited scope for improvement. The estimated treatment effect on the high school completion rate is 0.033 , amounting to a 3 percent improvement. Second, the simple and controlled difference in differences estimates of this treatment effect are similar, which is a result of the near perfect balancing between treatment and control in observables characteristics and in pre-reform outcomes. Third, the estimated coefficient on one of the four outcomes is not statistically significant and another one is only marginally significant. We later show that this lack of significance in the average effect is driven by the following heterogeneities of the effects: (1). There is no effect on students whose parents have high education levels, and high and significant effect for students whose parents have low levels of education. (2). There is only a small and insignificant effects on girls, but large and significant effect on boys. (3). There is smaller and less significant effect on students whose kibbutz reformed in the middle of their high school years, and larger and significant effect on students who spent their entire high school in a reformed kibbutz. We also note that the educational improvements due to the reform reflect mainly post-reform (1999-2000) differences between the treatment and control group while differences between these two groups before the reform (199519996) were small and insignificantly different from zero (these cross section comparisons are not shown in Table 6 but available from the authors). 
Turning to the estimated treatment effect on the other outcomes, the mean exam score is up by 3.55 points relative a pre-treatment mean of 70.6 , or 0.17 standard deviations of the test score distribution. The matriculation rate is up by 4.9 percentage points and the university qualified Bagrut rate is up by 6 percentage points, which amounts to almost 12 percent of the prereform university qualified Bagrut rate in the control group. The improvement in the university qualified Bagrut rate could be driven by two particular improvements. The first is an increase in the proportion of students who enroll in and pass the English matriculation program at more than a basic level. The second is an increase in the proportion of students who pass the matriculation program in at least one advanced placement subject. These two criteria are an admission requirement for all universities and most colleges Israel. The improvement we observe likely reflects a higher intention to enroll in post secondary schooling.

An implication of the identification assumption that the exact timing of the reform was unrelated to students' potential outcomes can be tested. Specifically, individuals aged 18 or older in 1998 were not exposed to the program. The increase in high school matriculation achievements between cohorts in this age group should thus not differ systematically across kibbutzim that adopted the reforms earlier and those that adopted them later. In Panel B of Table 6, we present this control experiment. We contrast the outcomes of two pre- reform cohorts, the 10th graders in 1995-1996 and the 10th graders in 1997-1998. These placebo estimated difference in differences are very different from the treatment estimates presented in Panel A of Table 6, and they are very close to zero. For example, the placebo estimate of the effect on average Bagrut score is 0.304 (s.e. 1.544) and the estimates on the two Bagrut diploma outcomes are actually negative, though not significantly different from zero. We also conduct a placebo test contrasting the outcomes of the $10^{\text {th }}$ graders in 1995 against the $10^{\text {th }}$ graders in 1996 and find similar results, i.e. no effect; results are available from the authors. These results provide additional suggestive evidence that the difference in differences estimates based on comparing the before and after cohorts are not driven by inappropriate identification assumptions.

\section{b. Allowing for differential effect by "intensity" of reform}

The pay reform was not identical across kibbutzim, as some reformed to a greater degree than others. Specifically, some kibbutzim introduced a full pay reform and moved to a "safety net" model that reflected market forces (and only a small additional safety net to low-earners). Other kibbutzim introduced only a partial pay reform and moved to a "combined" model (meshulav) that was still based on market forces, but combined them with a more progressive tax 
and wider safety net for members. ${ }^{19}$ However, many kibbutzim that initially introduced a partial reform eventually implemented a full differential pay reform

In this section we take advantage of the variation over time in the degree of pay reform, which is present because some kibbutzim changed immediately from an equal sharing system to a full differential pay system, while others introduced a partial differential pay system initially but later changed it to a complete differential pay structure. ${ }^{20} \mathrm{We}$ can exploit these changes to define treatment intensity because some of these kibbutzim made the change within the period of treatment. ${ }^{21}$ We therefore measure intensity of the pay reform by counting the number of years each student's kibbutz operated under a system of full differential pay while he was of high school age. We therefore define four treatment groups, ranging from 3 years of full reform to 0 years of full reform ( 3 years of partial reform). ${ }^{22}$

We perform balancing tests similar to those presented in Table 3, and the results suggest that the students in these four treatment groups are statistically indistinguishable from the students of the control group in their observed characteristics. In Online Appendix Tables A2 and A3 we present this evidence for the two cleanest treatment groups, namely the first and fourth. The balancing tests presented in Online Appendix Table A4 show that these two groups are also very similar to each other in terms of observed characteristics.

We then estimate the following controlled difference in differences model while including in the estimated model four treatment groups according to the value of the intensity measure:

$$
Y_{i j k c}=\gamma_{k}+\alpha_{c}+\beta_{j}(\text { AffectedCohort })+\delta X_{i k c}+\varepsilon_{i j k c}
$$

\footnotetext{
${ }^{19}$ Specifically, under the partial safety net model, a member got to keep a fraction of his earnings above a certain level and the rest of his earnings were shared equally among members.

${ }^{20}$ We note that no kibbutz moved from a full to partial pay system.

${ }^{21}$ Specifically, of the 37 kibbutzim that reformed in 1998, 17 introduced a full pay reform and 20 a partial reform, and of the latter group only 6 changed to a full reform within the treatment period (before 2003). Of the 14 kibbutzim that reformed in 1999, 7 introduced a full pay reform and 7 a partial reform; of the latter group 6 kibbutzim changed to full reform by 2002. Of the 22 kibbutzim that reformed in 2000, 13 introduced a full pay reform and 9 a partial reform; of the latter group 4 kibbutzim changed to full reform by 2002 .

${ }^{22}$ Specifically, the first treatment group includes students whose kibbutzim introduced a partial differential pay system initially and changed it only after they graduated from high school ( 3 years of partial reform); the second includes students whose first two years of high school were under partial differential pay system and whose last year was under full differential pay system (1 year of full reform); the third group includes students who were exposed to two years of a full differential pay system during high school (2 years of full reform), and the fourth group includes students who spent their entire high school under a full differential pay system ( 3 years of full reform). The first group account for thirty percent of the treated sample, the second 11 percent, the third 20 percent, and the fourth 39 percent.
} 
where $j$ is treatment intensity as defined above. $\beta_{j}$ are the coefficients of interest on the dummy variables indicating whether the student was treated with each of the four treatment intensities defined above.

The group with zero intensity of full pay had the lowest estimated effects, while the highest estimated effects are for the group with highest intensity of treatment. These results are presented in Table 7. The first panel presents the estimates with four intensity levels used as treatment measures. In panel B we use only two treatment groups, students exposed throughout high school (three years) to a partial pay reform versus students exposed to a full differential pay reform throughout their high school. Therefore panel B is based on a sample that excludes the two other treatment groups. The estimated effects of the lowest level of reform intensity on all four outcomes are very small and not significantly different from zero. On the other hand, the effect of being under a full differential pay system for 2 or 3 years has large and significant effect on all four outcomes. For example, the effect of three years in high school under a full differential pay system causes an 8.1 percentage point increase in the matriculation rate and 9.4 percentage point increase in the university qualified matriculation rate.

The results presented in panel B are very similar to the results in panel A and they reveal sharply the differences in estimated treatment effect of the full differential pay versus the zero estimated effect of the three years of partial differential pay system. Note that the size of the effect of the former is much larger than the average effect we presented in Table 6 for all outcomes besides high-school completion. For example, consider the treatment effect of the full differential pay system on the university qualified matriculation rate. This treatment effect is a 10.3 percentage points increase (up from average effect of 6 percentage points) in the university qualified matriculation rate, which amounts to a 20 percent increase relative to the counterfactual. The mean exam score is up by 4.43 , or 0.21 standard deviations of the test score distribution.

Overall, the evidence reported in Table 7 suggests the magnitude of the treatment effect increases with years of exposure to a system of full differential pay. Especially important is the much larger estimated effect of treatment based on three years of exposure relative to the effect of only one year of exposure, because it is based on a comparison of the same type of treatment but with different "intensities". 


\section{c. Allowing for Heterogeneous Effects}

\section{i. Heterogeneous effect by social background}

First, we look at whether the pay reform, full or partial, affected students with different social backgrounds differently. On the one hand, assuming a utility that is concave in income, we expect students from lower social classes to be more affected by the decrease in the income tax because a future dollar increase in earnings is more valuable for them. Moreover, we expect students from lower social backgrounds to be more affected by the change in return if they are less likely to have inherent motivation to invest in schooling and will only do so when given external incentives. On the other hand, students whose parents are more educated might receive more help at home or elsewhere, thus be in a better position to improve their schooling when given the incentives. We stratify the sample by parental schooling, splitting the sample into two groups as follows: students whose mothers have 13 or more years of schooling (50\% percent of students) and the rest. Similarly, we stratify the sample by the father's years of schooling and find similar results. ${ }^{23}$

The heterogeneous estimates by parental schooling presented in Panels A and B of Table 8 suggest that almost all the mean effects are coming from the sample of students for whom parents' schooling is below the median. Therefore these estimated treatment effects for these students are much larger than the basic results presented in Table 6, and their percentage increases are also larger because their counterfactual means are much lower than the mean of the overall sample (the means of all outcomes for each sub-group are presented in Table 8 in curly brackets, below the reported standard errors of each parameter). Based on partitioning the sample by mother's schooling, the estimated effect on high school completion is 0.049 (s.e. 0.024 ) for the students from low education families and 0.014 (s.e. 0.019) for pupils from high education families. ${ }^{24}$ The two respective difference in differences estimates are 6.175 (s.e. 2.553) and 0.329 (s.e. 2.114) for the average score, 0.116 (s.e. 0.053) and -0.031 (s.e. 0.047) for the Bagrut rate, and 0.100 (s.e. 0.053 ) and 0.002 (s.e. 0.048) for the university qualified Bagrut rate. The effect is larger in the low education sample. For example, the effect of the pay reform on the university

\footnotetext{
${ }^{23} \mathrm{We}$ also ran balancing tests like those reported in Table 3 for these sub-samples. The results (available from the authors) suggest that the treated and the respective control group have very similar characteristics, regardless of whether we stratify the sample by father's or by mother's schooling. The balancing tests of mean outcomes of pre-treatment cohorts show also close similarity between treatment and control except for marginally significant differences in two of the four outcomes when we stratify the sample by mother's schooling.

${ }^{24}$ We note that this higher effect on high school completion likely also reflect the "ceiling effect" on this outcome. That is, high school completions was already very high pre-treatment (95\%) suggesting a very limited role for improvement. Because students from low education families had a somewhat lower pretreatment high school completion rate, the treatment had more scope to improve their outcomes.
} 
qualified matriculation rate is a 21 percent increase $(0.100 / 0.478)$, twice the effect estimated for the whole sample.

The results stratified by father's schooling are very similar and the implied percentage increases in the low education group are again large, except for the effect on high school completion, which in this case does not differ between the two groups. Specifically, the estimated effect on high school completion is 0.033 (s.e. 0.027) for the students from low education families and 0.031 (s.e. 0.017) for pupils from high education families. Overall, as can be seen in the top panels of Table 8 , the estimates of the effect on the other outcomes are large and significant for the low education families but small and insignificant for students from high education families.

We next allow for heterogeneity of the effect by both parental education and intensity of reform simultaneously. Consistent with the evidence presented in this section and the previous one, Table 9 suggests that the treatment effect is the largest for students who were exposed to a full differential pay system throughout their high schools and whose parents have lower levels of education. The treatment effect of the full differential pay system for students from lower social backgrounds is a 4.4 percentage point increase in high school completion rates, an 8.3 point increase in mean exam score, a 19.6 percentage point increase in the matriculation rate, and a 16.8 percentage point increase in the university qualified matriculation rate. The gains in the matriculation rate represent a more than 30 percent improvement relative to the mean of the control group. In contrast, the intensity of the reform did not matter for students from high educational backgrounds. These results by parents' education level are the opposite of Jensen's (2010). We note that the less educated parents in the kibbutz are on average more educated than the more educated parents in the Dominican Republic, meaning that financial constraints are less important in our context. We again note that this finding that students whose parents are less educated respond more rules out a possible income effect, whereby we would expect more educated people who gained from the reform to respond more because they could invest more in their children's education. ${ }^{25}$

Our result that children from low educated families respond more strongly to the reduction in the income tax rate could reflect a higher rate of return to schooling perceived by this group. There is growing evidence that suggest that indeed the rate of return to schooling is higher among individuals who are more credit constrained, have

\footnotetext{
${ }^{25}$ However, less educated parents experienced a sharp decline in their income following the pay reform. This change may have triggered perhaps more effort on the part of children, maybe with encouragement of parents, to invest more in schooling in order to offset the lower well being associated with lower relative income at adulthood as suggested by the findings presented in Luttmer (2005).
} 
greater immediate need to work, or have greater distaste for school (Card, 1995 and 2001). Brenner and Rubinstein (2011) show evidence of higher return to schooling to individuals in poor families in the US.

\section{ii. Heterogeneous effect by gender}

Next we allow for heterogeneity by gender. Male and female students have been shown to respond differently to incentives (e.g. Schultz 2004, Angrist and Lavy 2009), with females typically being more responsive. However, our estimates stratified by gender, presented in Panel $\mathrm{C}$ of Table 8 suggest a stronger effect on males than on females, although the standard errors of the estimates are not precise enough to reject no gender differences. The estimated effect on high school completion is 0.052 (s.e. 0.023) for males and 0.011 (s.e. 0.019) for females, almost significantly different from each other. The two respective estimates for the average test scores are 4.820 and 2.549; similar relative gaps are evident for the two Bagrut diploma related outcomes.

Similarly, Table 10 suggests that the treatment effect is not only larger for students who were exposed to a full differential pay system throughout their high schools, but it is the largest for boys who were fully exposed. The treatment effect of the full differential pay system for boys is a 4.2 percentage point increase ( 0.8 percentage points for girls) in high school completion rates, a 6.0 point increase ( 2.8 for girls) in mean exam score, a 10 percentage point increase ( 3.5 for girls) in the matriculation rate, and a 9.6 percentage point increase (4.8 for girls) in the university qualified matriculation rate.

Our findings that boys are more affected by the pay reform, in particular in the school completion outcome, stand in contrast to Schultz (2004), who found that girls' school completion responded more to the incentives introduced by Progresa in Mexico. Our findings are also different from Angrist and Lavy (2009), who found that girls' Bagrut diploma attainment was affected by conditional bonus payments, whereas boys did not react to this monetary incentive. In these papers, girls responded more to an increase in incentives designed to directly increase educational outcomes. In our context, the pay reform does not increase such short run incentives to perform better in school. In contrast, the pay reform we study operates through affecting the future rewards in the labor market. It is possible that females perceive a lower return to education in the labor market, expect to work in lower paying jobs on average, perhaps because they do not expect to become the main earner (for example because they plan to play a bigger role in raising children). Indeed, in regressions we run using the 1998-2000 Israeli labor force surveys and matching occupations to their mean earnings using income surveys, we find that females (both in 
kibbutzim and outside them) are substantially more likely to work in lower paying occupations; they sort into occupations and industries that pay around 20\% less on average (regression results are available from the authors upon request).

These findings also contribute to our understanding of how the labor supply response to taxation differs by gender. While the literature suggests that men respond less to changes in income taxes in terms of hours worked, our findings suggest that they respond more in terms of investment in human capital.

\section{Putting the magnitude of the effects into perspective}

To put the magnitude of the effect we find on the matriculation rate into perspective, it is useful to compare our estimates with the effects of various forms of high school intervention that had the direct objective of raising the matriculation rate and were implemented in Israel around the same academic year, 2000-2001. ${ }^{26}$ The first is a remedial education program that provided individualized instruction to high school students in preparation for the matriculation exams (Lavy and Schlosser, 2005). The second is a student matriculation awards program that provided monetary bonuses to students who earned matriculation certificates (Angrist and Lavy, 2009), the third is a teacher-bonus program that paid math, English and Hebrew teachers bonuses on the basis of their students' performance on matriculation exams (Lavy, 2009), and the fourth is a school choice program that allowed students in Tel Aviv to freely choose their secondary school in $7^{\text {th }}$ grade (Lavy, 2010).

The effect of pay reform we study here was larger than the effect of these other programs, except for the remedial program. Specifically, the remedial program produced a gain similar to that of the pay reform we study here: an increase of 12 percentage points in the matriculation rate of participants in comparison to a gain of 10 percentage points caused by a full differential pay reform. Note however, that the remedial program was targeted to students with low probability of passing some of the Bagrut exams while the pay reform affected students with a much higher Bagrut passing rate. The students' bonus program increased the matriculation rate by 6 percentage points, though the gain was mainly among girls. The teacher bonus program increased the matriculation rate by 3.3 percent, while the school choice program led to a 6.2 percentage point increase in the matriculation rate. However, we note that the first three of these interventions involved only one year of treatment while the pay reform we study in this paper

\footnotetext{
${ }^{26}$ We note that those interventions were local and did not affect students in our sample.
} 
involved three years of treatment. We also note that unlike these alternative programs, the pay reform was not an explicit intervention that targeted improvements in matriculation outcomes.

\section{Conclusions and Implications}

In this paper we use a natural experiment to test whether and to what extent investment in education is responsive to changes in the redistributive policy that changes the returns to education. This is, to the best of our knowledge, the first study that uses non-experimental data with an actual change in the rate of return to schooling to study the impact of an increase in the benefit from schooling on human capital investment.

The natural experiment that we exploit in this study is the reforms instituted by many Israeli kibbutzim in the late 1990s and early 2000s. These reforms took many kibbutzim from paying all their members the same wage regardless of their human capital and the jobs they performed, to paying wages based on the market rate of return to schooling. These reforms caused a sharp and salient increase in the returns to education for kibbutz members. We rely on this sharp change to test whether and to what extent an effective decrease in the income tax rate, which substantially increases the return to schooling, induces high school students to invest more in their education, as reflected in their academic achievements.

We use a difference-in-differences approach and take advantage of the fact that different kibbutzim reformed at different times for our identification. Specifically, we compare educational outcomes of high school students in kibbutzim that reformed early (the treatment group) and late (the control group), before and after the early reforms (but before the late reforms). The treatment group is nearly identical to the control group in observable pre-determined characteristics and pre-reform mean outcomes. We find students are indeed responsive to changes in returns to education: when their kibbutzim reformed, they considerably improved their educational outcomes such as whether they graduated and their average matriculation exam scores. Students who spent their entire three years of high school in a kibbutz that reformed to a greater extent improved their educational outcomes more. Males reacted more strongly than females, and students with less educated parents reacted much more strongly than those with more educated parents.

Beyond showing that the students in kibbutzim that reformed early are identical to students in kibbutzim that reformed few years later in observables and pre reform outcomes, we provide several other reasons why other selection or sorting is not likely responsible for the results summarized above. For example, families of boys and girls in each kibbutz were potentially similarly sorted or selected, so if sorting is producing our results, we should have obtained similar rather than very different results for males vs. females. This argument is equally valid with 
respect to our evidence of heterogeneous effect by high and low education families in the kibbutz. In addition, there does not appear to be any sorting in terms of pre-reform differences between treatment and control kibbutzim in time trends of educational outcomes and in exit rates. All of this evidence supports a causal interpretation for the estimated effects summarized above.

While a main advantage of our setting is the high internal validity of the estimates, we believe that our findings are also externally valid because they have implications beyond the Israeli context. First, they shed light on the educational responses that could result from a decrease in the income tax rate, thus are informative on the long-run labor supply responses to tax changes. Second, they shed light on the educational responses expected when the returns to education increase. For example, such changes might be occurring in many countries as technology-oriented growth increases the return to skills. ${ }^{27}$ While the pay reform in kibbutzim is likely larger than many other policy changes aiming to reduce the income tax rates or increase the rates of return to education, there have been other important episodes with similarly large reforms. First, the transition from a centrally planned to a market economy in the former Soviet republics and in Eastern Europe is an important historical development that resulted in an increase in the rate of return to schooling. Brainerd (1998) shows that the transition to a market economy has produced a substantial and rapid change in the wage structure in Russia, the overall wage inequality nearly doubled from 1991 to 1994 and the returns to education have increased considerably. Similar findings are reported by Svejnar (1999) for transitional Central and Eastern European economies. While our results are silent on the general equilibrium effects that could result from such huge economy-wide changes, they shed light on the likely impact these changes had on human capital investment in the former Soviet nations and former European communist countries. Second, our findings may suggest the likely human capital consequences in developing countries that substantially liberalized their labor markets, for example Vietnam in the mid 1980 's, ${ }^{28}$ and as a result experienced increases in the returns to schooling. Finally, our findings may improve our understanding of the large human capital gap between first and second generation immigrants in developed countries. ${ }^{29}$ Our findings suggest that part of the higher education of immigrants' children from some countries could be due to the higher rates of return to schooling they experience in their host countries relative to the returns in their home countries. Furthermore, we note that the increase in redistribution in kibbutzim that reformed partially was more similar to changes in redistributive policies elsewhere in the developed world. Our findings suggest that

${ }^{27}$ See, for example, the discussion in Autor, Katz and Krueger (1999), Card and Dinardo (2002), and Golding and Katz (2008).

${ }^{28}$ See Moock, Patrinos and Venkataraman (1998).

${ }^{29}$ See Dustmann and Theodoropoulos (2010) and Aydemir and Sweetman (2006). 
moderate increase in the redistributive policy will still induce educational responses, although the estimated effect of a partial reform are less precisely measured.

Our findings also contribute to the literature on the increase in earnings inequality in the US and many other developed countries over the past decades, which perhaps is one of the most important aggregate phenomena in labor markets since WWII (known as "Skilled Bias Technological Changes"). Large body of research focused on the implications of technological advancement for the demand for skill (see Katz and Autor, 1999 and recent updates of this survey). Yet, no attention was given to estimating the impact of the returns to education on the supply of educated workers, which is a key factor for understanding the longer-run consequences of changes in the demand structure in the era of "Skilled Bias Technological Changes". To the best of our knowledge this paper is the first to tackle this question. Estimating the supply elasticity requires an external source of variation in the returns to education, solely driven by demand factors, and independent of preexisting stocks and current flows of skilled labor. This might explain the lack of credible empirical research on this front. The experience of the Israeli economy during the 1980s-1990s in general and the kibbutzim communities in particular provides a unique setting for estimating the causal impact of the returns to education on school choices and the supply of educated workers. 


\section{References}

Alesina, Alberto, Andrea Ichino, and Loukas Karabarbounis, "Gender Based Taxation and the Division of Family Chores," NBER Working Papers 13638, 2007.

Abramitzky, Ran, "The Limits of Equality: An Economic Analysis of the Israeli Kibbutz," Northwetern University Dissertation, 2005.

Abramitzky, Ran, “The Limits of Equality: Insights from the Israeli Kibbutz," Quarterly Journal of Economics, 123:3, 1111-1159, 2008.

Abramitzky, Ran, "The Effect of Redistribution on Migration: Evidence from the Israeli kibbutz," Journal of Public Economics, 93, 498-511, 2009.

Abramitzky, Ran, "Lessons from the Kibbutz on the Equality-Incentives Trade-Off," Journal of Economic Perspectives, 25:1, 185-208, 2011.

Angrist, D. Joshua, and Victor Lavy, "The Effect of High-Stakes High School Achievement Awards: Evidence from a Group-Randomized Trial," American Economic Review, 99:4, 1384-1414, 2009.

Attansio, Orazio Pietro, and Katja Maria Kaufmann, "Educational Choices, Subjective Expectations, and Credit Constraints," NBER Working Paper 15087, 2009.

Autor, David, Lawrence Katz, and Alan B. Krueger, “Computing Inequality: Have Computers Changed the Labor Market?” Quarterly Journal of Economics 113, 1169-1214, 1999.

Autor, David H., Lawrence F. Katz and Melissa S. Kearney "Trends in U.S. Wage Inequality: Revising the Revisionists", Review of Economics and Statistics, 90(2), 300-323, 2008.

Avery, Christopher, and Thomas J. Kane, "Student Perceptions of College Opportunities: The Boston COACH Program," in Hoxby, Caroline M., ed., College Choices: The Economics of Where to Go, When to Go, and How to Pay for It, Chicago: University of Chicago Press, 2004.

Aydemir, Abdurrahman, and Arthur Sweetman, "First and Second Generation Immigrant Educational Attainment and Labor Market Outcomes: A Comparison of the United States and Canada," IZA Discussion Paper No. 2298, 2006.

Brainerd, Elizabeth, "Winners and Losers in Russia's Economic Transition," American Economic Review, 88:5, 1094-1116, 1998.

Becker, Gary, Human Capital and the Personal Distribution of Income, Ann Arbor Michigan: University of Michigan Press, 1967.

Ben-Porath, Yoram, "The Production of Human Capital and the Life Cycle of Earning," Journal of Political Economy, 75, 352-365, 1967.

Betts, Julian, "What Do Students Know About Wages? Evidence From a Survey of Undergraduates," Journal of Human Resources, 31:1, 27-56, 1996.

Brenner, Dror, and Yona Rubinstein, "Be Heedful the Children of the Poor for from Them Torah Goeth Forth: The Returns to Schooling and Family Income," presented at Workshop on: "Frontiers in Economics of Education," The Eitan Berglas School of Economics, Tel Aviv University, Monday, June 21-23, 2010. 
Card, David, "Using Geographic Variation in College Proximity to Estimate the Return to Schooling," in Louis N Christofides, E. Kenneth Grant and Robert Swidinksy, eds., Aspects of Labour Market Behaviour, Toronto: University of Toronto Press, 1995.

- - "The Causal Effect of Education on Earnings," in Orley Ashenfelter and David Card, eds., Handbook of Labor Economics, Volume 3A, Amsterdam and New York: North Holland, 1999.

Card, David, "Estimating the Return to Schooling: Progress on Some Persistent Econometric Problems," Econometrica, 69:5, 1127-1160, 2001.

Card, David, and John DiNardo, "Skill-Biased Technological Change and Rising Wage Inequality: Some Problems and Puzzles," Journal of Labor Economics, 20:4, 733-783, 2002.

Chetty, Raj, John Friedman, Tore Olsen, and Luigi Pistaferri, "Adjustment Costs, Firm Responses, and Micro vs. Macro Labor Supply Elasticities: Evidence from Danish Tax Records," forthcoming Quarterly Journal of Economics.

Dale, Stacy Berg, and Alan B. Krueger, "Estimating The Payoff To Attending A More Selective College: An Application Of Selection On Observables And Unobservables," The Quarterly Journal of Economics, 117:4, 1491-1527, 2002.

Dominitz, Jeff and Charles F. Manski, "Eliciting Student Expectations of the Returns to Schooling," Journal of Human Resources, 31:1, 1-26, 1996.

Dustmann, Christian, and Nikolaos Theodoropoulos, "Ethnic minority immigrants and their children in Britain," Oxford Economic Papers, Oxford University Press, 62:2, 209-233, 2010.

Freeman, Richard B., The Overeducated American, New York: Academic Press, 1976.

Gavron, Daniel, The Kibbutz: Awaking from Utopia, Lanham, MD, 2000.

Getz, Shlomo, "Surveys of Changes in Kibbutzim," Institute for Research of the Kibbutz and the Cooperative Idea, University of Haifa, Reports, 1998-2004 (in Hebrew).

Gilboa, Yaakov, "Kibbutz Education: Implications for Nurturing Children From Low-Income Families," Israel Economic Review, 12, 107-123, 2004.

Goldin, Claudia, and Lawrence Katz, The Race between Education and Technology, Cambridge, MA: The Belknap Press of Harvard University Press, 2008.

Hoxby, Caroline M., "The Return to Attending a More Selective College: 1960 to the Present," Forum Strategy Series, 3, 2000.

Jensen, Robert, "The (Perceived) Returns to Education and the Demand for Schooling," Quarterly Journal of Economics, 125:2, 515 -548, 2010.

Kane, Thomas J., "College Entry by Blacks since 1970: The Role of College Costs, Family Background, and Returns to Education,” Journal of Political Economy, 102:5, 878-911, 1994.

Kane, Thomas J., and Cecilia Rouse, "Labor Market Returns to Two- and Four- Year Colleges: Is a Credit a Credit and Do Degrees Matter?” NBER Working Paper 4268, 1993.

Katz Lawrence, and Kevin Murphy, "Changes in Relative Wages, 1963-1987: Supply and Demand Factors," Quarterly Journal of Economics, 107, 35-78, 1992.

Katz Lawrence, and David Autor, "Changes in the Wage Structure and Earnings Inequality," in O. Ashenfelter and D. Card, eds., Handbook of Labor Economics, vol. 3A, NorthHolland, 1463-1555, 1999. 
Klinov, Ruth, and Michal Palgi, "Standard of Living in Kibbutzim - a comparison with Urban Families," Working Paper Number A06.05, The Falk Research Institute, Jerusalem Israel, 2006.

Lavy, Victor, and Analia Schlosser, "Targeted Remedial Education for Under-Performing Teenagers: Costs and Benefits,” Journal of Labor Economics, 23:4, 839-874, 2005.

Lavy, Victor, "Performance Pay and Teachers' Effort, Productivity and Grading Ethics," American Economic Review, 99:5, 1979-2011, 2009.

Lavy, Victor, "Effects of Free Choice among Public Schools," Review of Economic Studies 77, 1164-1191, 2010.

Luttmer, Erzo F.P., "Neighbors as Negatives: Relative Earnings and Well-Being," Quarterly Journal of Economics, 120:3, 963-1002, 2005.

Manski, Charles F., "Adolescent Econometricians: How Do Youth Infer the Returns to Education?" in Clotfelter, Charles T. and Michael Rothschild, eds., Studies of Supply and Demand in Higher Education, Chicago, Ill: University of Chicago Press, 1993.

Martorell, Francisco, "Do High School Graduation Exams Matter? Evaluating the Effects of Exit Exam Performance on Student Outcomes," Manuscript, 2005.

Millett, Bryce, and Emily Oster, "Do Call Centers Promote School Enrollment? Evidence from India” Draft, February, 2011.

Moock Peter R., Harry A. Patrinos and Meera Venkataraman, "Education and Earnings in a Transition Economy (Vietnam)," World Bank Policy Research Working Paper No. 1920, 1998.

Oreopoulos, Philip, and Kjell Salvanes, "How Large Are the Returns to Schooling? Hint: Money Isn’t Everything," NBER Working Paper 15339, 2009.

Sakellaris, Plutarchos, and Antonio Spilimbergo, "Business cycles and investment in human capital: international evidence on higher education," Carnegie-Rochester Conference Series on Public Policy, 52, 221-256, 2000.

Saez, Emmanuel, Joel B. Slemrod, and Seth H. Giertz, "The Elasticity of Taxable Income With Respect To Marginal Tax Rates: A Critical Review," Working Paper 15012, 2009.

Schultz, T. Paul, "School Subsidies for the Poor: Evaluating the Mexican Progresa Poverty Program," Journal of Development Economics, 74(1): 199-250, 2004.

Smith, Herbert L., and Brian Powell, "Great Expectations: Variations in Income Expectations Among College Seniors," Sociology of Education, 63:3, 194-207, 1990.

Svejnar, Jan, "Labor Markets in the Transitional Central and East European Economies", in Orley Ashenfelter and David Card (eds.), Handbook of Labor Economics, Vol. 3, North Holland, 1999.

Trumper, Ricardo, "Differences in Motivation Towards Science Subjects Among Kibbutz and Urban High School Students," Interchange, 28:2, 205-218, 1997.

Weiss, Andrew, "Human Capital vs. Signalling Explanations of Wages," Journal of Economic Perspectives, 4, 133-154, 1995. 
Figure 1: Difference in differences strategy: timeline

pre-reform cohort post-reform cohort

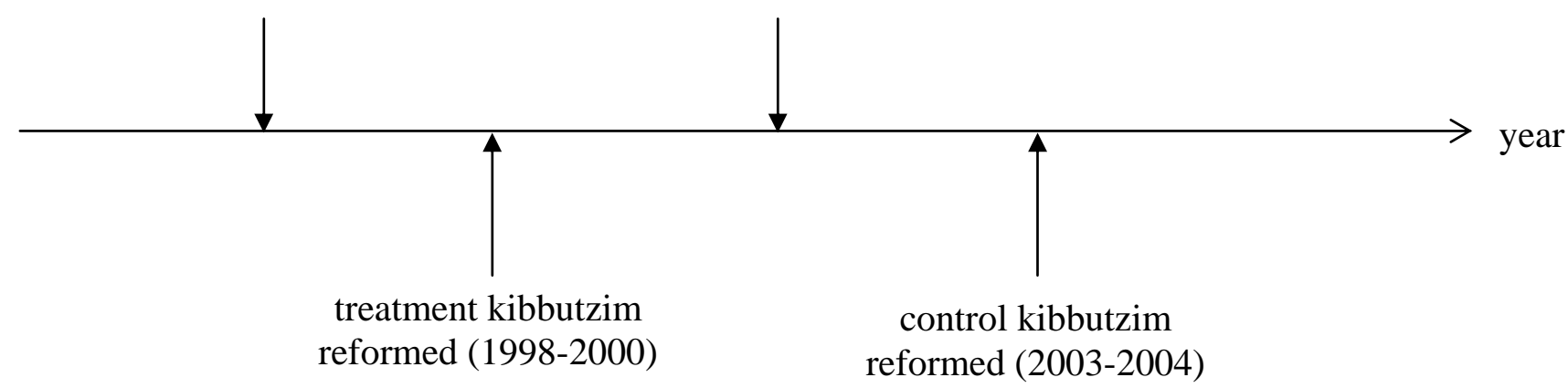

Notes: As our first difference, we compare students in kibbutzim that reformed early (1998-2000) as the "treatment group", with students in kibbutzim that reformed late (2003-2004) as the "control group". As our second difference, we compare students who were in high school after the early reforms but before the late reforms $\left(10^{\text {th }}\right.$ grade students in 1999 and 2000), with those who were in high school before the early reform $\left(10^{\text {th }}\right.$ grade students in 1995 and 1996).

\section{Figure 2: Wage by Education, Before and After the Reform}

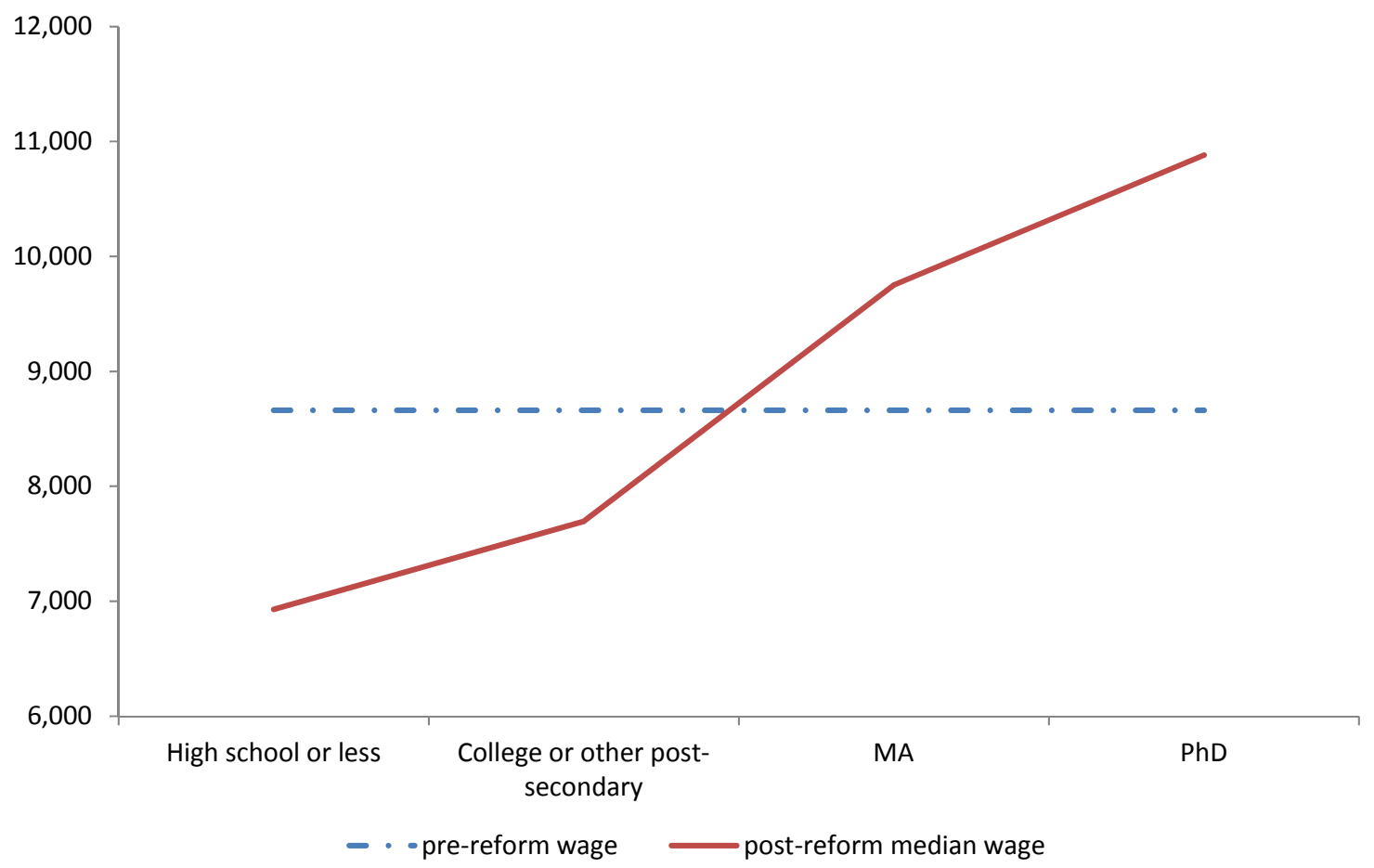

Notes: The figure plots median wages by education of all working members in one particular kibbutz pre and post reform Wages are measured in 2010 New Israeli Shekels per month. 1 US dollar is currently equal to approximately 3.6 shekels. 
Table 1: Post Reform Wage by Education of All Working Members in Two Kibbutzim

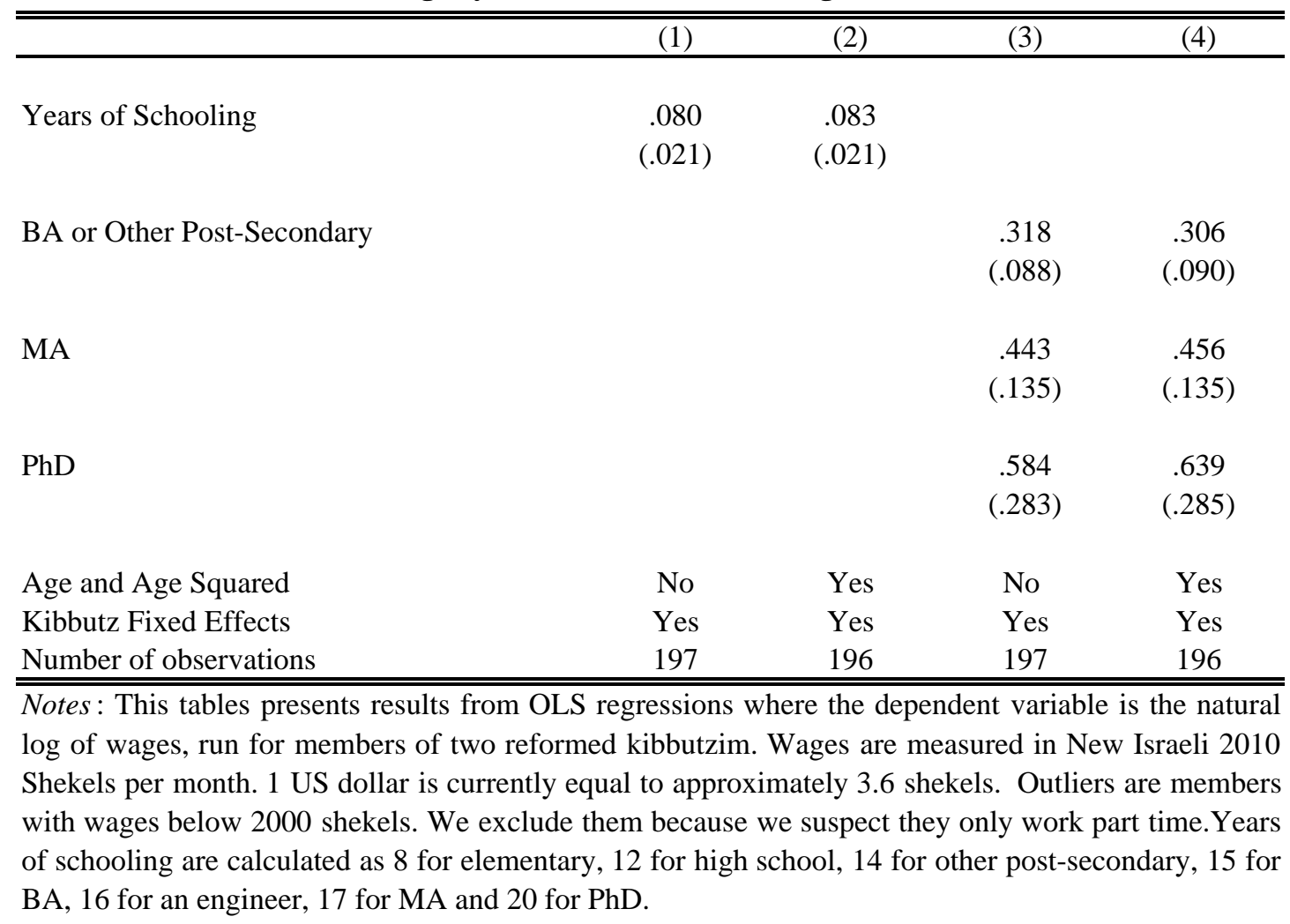


Table 2: Distribution of Kibbutzim, Schools and Students by Year of Reform and by 10th Grade Cohorts

\begin{tabular}{lcc}
\hline \hline & \multicolumn{2}{c}{ Year of Reform } \\
\cline { 2 - 3 } & $\begin{array}{c}1998-2000 \\
\text { (Treatment) }\end{array}$ & $\begin{array}{c}\text { 2003-2004 } \\
\text { (Control) }\end{array}$ \\
\cline { 2 - 3 } & & $(1)$ \\
\hline \hline A. 10th Grade Students in 1995-1996 & 74 & 33 \\
Kibbutzim & 1,100 & 601 \\
Students & & 33 \\
B. 10th Grade Students in 1999-2000 & 74 & 605 \\
Kibbutzim & 1,043 & \\
Students & & \\
\hline
\end{tabular}

Notes: This table presents the number of kibbutzim and students in the treatment and control kibutzim and treated (10th grade in 1999-2000) and untreated (10th grade in 1995-96) cohorts. 
Table 3: Balancing Tests of Students' Characteristics and Outcomes in Treatment and Control Kibbutzim

\begin{tabular}{|c|c|c|c|c|c|c|}
\hline & \multicolumn{3}{|c|}{$\begin{array}{l}\text { 10th Grade Students } \\
\text { in } 1995 \text { and } 1996\end{array}$} & \multicolumn{3}{|c|}{$\begin{array}{l}\text { 10th Grade Students } \\
\text { in } 1999 \text { and } 2000\end{array}$} \\
\hline & Treatment & Control & Difference & Treatment & Control & Difference \\
\hline & (1) & (2) & (3) & (4) & (5) & (6) \\
\hline \multicolumn{7}{|l|}{ A. Student's Characteristics } \\
\hline Male & $\begin{array}{c}0.495 \\
(0.500)\end{array}$ & $\begin{array}{c}0.507 \\
(0.500)\end{array}$ & $\begin{array}{l}-0.013 \\
(0.027)\end{array}$ & $\begin{array}{c}0.523 \\
(0.500)\end{array}$ & $\begin{array}{c}0.536 \\
(0.499)\end{array}$ & $\begin{array}{l}-0.012 \\
(0.023)\end{array}$ \\
\hline Father's Years of Schooling & $\begin{array}{c}13.26 \\
(2.776)\end{array}$ & $\begin{array}{c}13.59 \\
(2.841)\end{array}$ & $\begin{array}{l}-0.328 \\
(0.264)\end{array}$ & $\begin{array}{c}13.60 \\
(2.525)\end{array}$ & $\begin{array}{c}14.12 \\
(2.973)\end{array}$ & $\begin{array}{l}-0.523 \\
(0.419)\end{array}$ \\
\hline Mother's Years of Schooling & $\begin{array}{c}13.42 \\
2.47\end{array}$ & $\begin{array}{c}13.71 \\
2.44\end{array}$ & $\begin{array}{l}-0.292 \\
(0.174)\end{array}$ & $\begin{array}{c}13.94 \\
2.23\end{array}$ & $\begin{array}{c}14.08 \\
2.25\end{array}$ & $\begin{array}{l}-0.140 \\
(0.229)\end{array}$ \\
\hline Number of Siblings & $\begin{array}{c}2.56 \\
(1.357)\end{array}$ & $\begin{array}{c}2.65 \\
(1.358)\end{array}$ & $\begin{array}{l}-0.094 \\
(0.199)\end{array}$ & $\begin{array}{c}2.53 \\
(1.249)\end{array}$ & $\begin{array}{c}2.77 \\
(1.581)\end{array}$ & $\begin{array}{l}-0.239 \\
(0.280)\end{array}$ \\
\hline Ethnic Origin: Africa/Asia & $\begin{array}{c}0.105 \\
(0.306)\end{array}$ & $\begin{array}{c}0.103 \\
(0.304)\end{array}$ & $\begin{array}{c}0.001 \\
(0.016)\end{array}$ & $\begin{array}{c}0.091 \\
(0.288)\end{array}$ & $\begin{array}{c}0.079 \\
(0.270)\end{array}$ & $\begin{array}{c}0.012 \\
(0.021)\end{array}$ \\
\hline Ethnic Origin: Europe/America & $\begin{array}{c}0.346 \\
(0.476)\end{array}$ & $\begin{array}{c}0.379 \\
(0.486)\end{array}$ & $\begin{array}{l}-0.033 \\
(0.035)\end{array}$ & $\begin{array}{c}0.360 \\
(0.480)\end{array}$ & $\begin{array}{c}0.306 \\
(0.461)\end{array}$ & $\begin{array}{c}0.054 \\
(0.033)\end{array}$ \\
\hline Immigrants from Non-FSU Countries & $\begin{array}{c}0.016 \\
(0.127)\end{array}$ & $\begin{array}{c}0.015 \\
(0.122)\end{array}$ & $\begin{array}{c}0.001 \\
(0.006)\end{array}$ & $\begin{array}{c}0.013 \\
(0.115)\end{array}$ & $\begin{array}{c}0.013 \\
(0.114)\end{array}$ & $\begin{array}{c}0.000 \\
(0.006)\end{array}$ \\
\hline Immigrants from FSU Countries & $\begin{array}{c}0.013 \\
(0.112)\end{array}$ & $\begin{array}{c}0.017 \\
(0.128)\end{array}$ & $\begin{array}{l}-0.004 \\
(0.007)\end{array}$ & $\begin{array}{c}0.031 \\
(0.173)\end{array}$ & $\begin{array}{c}0.023 \\
(0.150)\end{array}$ & $\begin{array}{c}0.008 \\
(0.009)\end{array}$ \\
\hline
\end{tabular}

\section{B. High School Outcomes}

$\begin{array}{lccc}\text { High School Completion } & 0.951 & 0.967 & -0.016 \\ & (0.216) & (0.180) & (0.011) \\ \text { Mean Matriculation Score } & 70.62 & 72.48 & -1.862 \\ & (23.250) & (21.039) & (1.309) \\ \text { Matriculation Certification } & & & \\ & 0.549 & 0.569 & -0.020 \\ \text { University Qualified Matriculation } & (0.498) & (0.496) & (0.036) \\ & & & \\ & 0.516 & 0.536 & -0.019 \\ & (0.500) & (0.499) & (0.035)\end{array}$

Observations

1,100

601

1,043

605

Notes: Columns 1, 2, 4 and 5 present means and standard deviations (in parentheses) of characteristics and outcomes of students in treatment and control kibbutzim for affected (1999-2000) and unaffected (1995-1996) cohorts of 10th graders. Columns 3 and 6 present the differences between treatment and control kibbutzim from regression equation (3). Standard errors of these differences clustered at the kibbutz level are given in parentheses. Treatment kibbutzim are those that reformed in 1998-2000. Control kibbutzim are those that reformed in 2003-2004. 
Table 4: Treatment-Control and Between-Cohort Differences in Students' Exit Rates From Their Kibbutzim

\begin{tabular}{lccc}
\hline \hline & Treatment & Control & Difference \\
\cline { 2 - 4 } & $(1)$ & $(2)$ & $(3)$ \\
\hline \hline 10th Grade Students in 1995-1996 & 0.056 & 0.042 & 0.015 \\
& $(0.231)$ & $(0.200)$ & $(0.016)$ \\
10th Grade Students in 1999-2000 & 0.052 & 0.038 & 0.014 \\
& $(0.222)$ & $(0.191)$ & $(0.011)$ \\
Difference & & & - \\
& -0.005 & -0.004 & - \\
& $(0.010)$ & $(0.016)$ & \\
\hline
\end{tabular}

Notes: This table presents exit rates from their kibbutzim of three cohorts of students in treatment and control kibbutzim. Columns 1 and 2 show means and standard deviations (in parentheses) of exit rates for the different groups of students. Column 3 shows differences between the groups and standard errors of the differences clustered at the kibbutz level (in parentheses), estimated from equation (4) in the text. Exit is defined as living in the kibbutz at the start of 10th grade, and living outside the kibbutz by the end of 12th grade. Treatment kibbutzim are those that reformed in 1998-2000. Control kibbutzim are those that reformed in 2003-2004. 
Table 5: Treatment-Control Differences in Pre-Reform Time Trends in Schooling Outcomes, 10th Grade Students in 1993-1998

\begin{tabular}{|c|c|c|c|c|}
\hline & \multicolumn{2}{|c|}{ Matriculation Certification } & \multicolumn{2}{|c|}{ Mean Matriculation Sco } \\
\hline & (1) & $(2)$ & (3) & (4) \\
\hline A. Linear Trend Model & & & & \\
\hline Time Trend & $\begin{array}{c}0.025 \\
(0.011)\end{array}$ & $\begin{array}{c}0.026 \\
(0.010)\end{array}$ & $\begin{array}{c}1.225 \\
(0.478)\end{array}$ & $\begin{array}{c}1.287 \\
(0.451)\end{array}$ \\
\hline Treatment $\mathrm{x}$ Time Trend & $\begin{array}{l}-0.008 \\
(0.013)\end{array}$ & $\begin{array}{l}-0.006 \\
(0.012)\end{array}$ & $\begin{array}{c}-0.267 \\
(0.580)\end{array}$ & $\begin{array}{c}-0.361 \\
(0.547)\end{array}$ \\
\hline Treatment & $\begin{array}{c}0.005 \\
(0.050)\end{array}$ & - & $\begin{array}{c}0.681 \\
(2.270)\end{array}$ & - \\
\hline
\end{tabular}

\section{B. Cohort Dummies Model}

Treatment x 1994

Treatment x 1995

Treatment x 1996

Treatment x 1997

Treatment x 1998

Treatment

Kibbutz Fixed-Effects

$\begin{array}{cccc}-0.022 & -0.005 & 2.178 & 2.329 \\ (0.076) & (0.070) & (3.481) & (3.295)\end{array}$

$\begin{array}{llll}-0.011 & 0.003 & -1.716 & -1.782\end{array}$

(0.075)

(0.070)

(3.446)

$\begin{array}{cccc}-0.030 & -0.008 & 0.403 & 0.024 \\ (0.075) & (0.070) & (3.446) & (3.255)\end{array}$

$\begin{array}{cccc}0.036 & 0.051 & 1.765 & 0.816 \\ (0.075) & (0.070) & (3.449) & (3.259)\end{array}$

$\begin{array}{llll}-0.087 & -0.074 & -2.019 & -1.962\end{array}$

(0.075) (0.069)

(3.416)

$-0.002$

$-$

$-0.358$

(2.424)

\begin{tabular}{|c|c|}
\hline YES & YES \\
\hline$F(5,488)=0.66$ & $F(5,488)=0.48$ \\
\hline Prob $>F=0.6516$ & Prob $>F=0.7897$ \\
\hline
\end{tabular}

Notes: This table presents the results from OLS regressions run at the kibbutz level predicting the proportion of students who received matriculation certificates (columns 1 and 2) or the mean scores in the matriculation exams (columns 3 and 4) for the cohorts of 10th graders from 1993 to 1998 (pre reform). In the regressions in Panel A, outcomes are allowed to vary according to a linear time (cohort) trend that differs in treatment and control kibbutzim, as described in regression equation (5). In the regressions in Panel $\mathrm{B}$, the difference between treatment and control kibbutzim is allowed to vary freely for each cohort of students. Cohort dummies are included in the Panel B regressions but their coefficients are not reported. Estimates in columns 2 and 4 include kibbutz fixed effects. Standard errors are presented in parentheses. The number of observarions in each regression is 605. The $\mathrm{F}$ statistics at the bottom of the table test whether all the interaction terms in Panel B between treatment kibbutzim and the cohorts are jointly zero. 
Table 6: Cross-Section Treatment-Control Differences and Difference in Differences Estimates

\begin{tabular}{cccccc}
\hline \hline & High School & Mean & Matriculation \\
Completion & $\begin{array}{c}\text { University } \\
\text { Qualified } \\
\text { Score }\end{array}$ & $\begin{array}{c}\text { Certification } \\
\text { Matriculation }\end{array}$ \\
\cline { 2 - 6 } & $(1)$ & $(2)$ & $(3)$ & $(4)$ \\
\hline \hline
\end{tabular}

\section{A. Experiment of Interest, 10th Grade Students in 1995-1996 and 1999-2000}

\section{Difference in Differences Regressions}

$\begin{array}{lcccc}\text { Simple Difference in Differences } & 0.033 & 3.112 & 0.029 & 0.040 \\ & (0.016) & (1.517) & (0.035) & (0.035) \\ \text { Controlled Difference in Differences } & 0.033 & 3.546 & 0.049 & 0.060 \\ & (0.015) & (1.604) & (0.035) & (0.035)\end{array}$

\section{B. Control Experiment, 10th Grade Students in 1995-1996 and 1997-1998}

\section{Difference in Differences Regressions}

$\begin{array}{lcccc}\text { Simple Difference in Differences } & 0.011 & 0.213 & -0.016 & -0.025 \\ & (0.015) & (1.527) & (0.036) & (0.036) \\ \text { Controlled Difference in Differences } & 0.011 & 0.304 & -0.013 & -0.027 \\ & (0.015) & (1.544) & (0.035) & (0.035)\end{array}$

Notes: The first half of Panel A presents the coefficients of interest in single difference regressions comparing outcomes of students of the same cohort between treatment kibbutzim (reformed in 1998-2000) and control kibbutzim (reformed in 2003-04). The dependent variable in column 1 is whether the student completed high school; in column 2 it is her mean score in the matriculation exams; in column 3 it is whether she received a matriculation certificate; in column 4 it is whether she received a matriculation certificate that satisfies the requirements for university study.

The second half of Panel A presents the coefficients of interest in difference-in-differences regressions comparing students in treatment and control kibbutzim who are treated (10th grade in 1999-2000) and untreated (10th grade in 1995-96). The single difference and simple difference-in-differences regressions include cohort dummies and standard errors (in parentheses) are clustered at the kibbutz level. The controlled difference-in-differences estimation (equation (2) in the text) include cohort dummies, kibbutz fixed effects, and the demographic controls gender, father's and mother's education, number of siblings, a set of ethnic dummies (origin from Africa/Asia, Europe/America, immigrants from FSU, Ethiopia and other countries). Panel B presents difference-in-differences regressions parallel to those in Panel A, but that compare two untreated cohorts. For the controlled difference-indifferences regressions, robust standard errors are presented in parentheses. 
Table 7: Controlled Difference in Differences Estimates by Level of Intensity of Exposure to Full Differential Pay

\begin{tabular}{cccccc}
\hline \hline & $\begin{array}{c}\text { High School } \\
\text { Completion }\end{array}$ & $\begin{array}{c}\text { Mean } \\
\text { Matriculation } \\
\text { Score }\end{array}$ & $\begin{array}{c}\text { Matriculation } \\
\text { Certification }\end{array}$ & $\begin{array}{c}\text { University } \\
\text { Qualified } \\
\text { Matriculation }\end{array}$ \\
\cline { 2 - 6 } & $(1)$ & $(2)$ & $(3)$ & $(4)$ & $(4)$ \\
\hline \hline
\end{tabular}

\section{A. Intensity of Exposure}

$\begin{array}{lcccc}\begin{array}{l}\text { Three Years of Full Reform } \\ \text { (N=405) }\end{array} & 0.029 & 4.288 & 0.082 & 0.100 \\ & (0.019) & (2.055) & (0.043) & (0.043) \\ \text { Two Years of Full Reform } & & & & 0.083 \\ \text { (N=211) } & 0.054 & 5.621 & 0.031 & (0.047) \\ & (0.018) & (1.925) & (0.047) & \\ \text { One Year of Full Reform } & 0.053 & 3.744 & 0.009 & -0.020 \\ \text { (N=114) } & (0.024) & (2.485) & (0.058) & (0.059) \\ & & & & 0.025 \\ \text { Three Years of Partial Reform } & 0.016 & 1.239 & 0.036 & (0.045) \\ \text { (N=313) } & (0.020) & (2.202) & (0.045) & \end{array}$

\section{B. Intensity of Exposure: partial versus full}

$\begin{array}{lcccc}\begin{array}{l}\text { Three Years of Full Reform } \\ \text { (N=405) }\end{array} & 0.030 & 4.431 & 0.084 & 0.103 \\ & (0.019) & (2.064) & (0.043) & (0.043) \\ \text { Three Years of Partial Reform } & & & & \\ (\mathrm{N}=313) & 0.015 & 1.285 & 0.035 & 0.026 \\ & (0.021) & (2.219) & (0.046) & (0.046)\end{array}$

Notes : This table presents the results of difference-in-differences regressions comparing students in treatment (reformed 19982000) and control (reformed 2003-04) kibbutzim who are treated (10th grade in 1999-2000) and untreated (10th grade in 199596), where the treatment effect varies by the number of years the student spent in high school under a full relative to partial differential pay system (versions of equation (7) in the text). The value of $\mathrm{N}$ for each intensity of treatment is the number of students who faced that intensity of treatment. The Panel A regressions interact dummies for the number of years each treated student spent in high school under a full differential pay system with the treatment cohort dummy.

Panel B regressions duplicate panel A regressions, but omit students who spent some high school years under a partial differential pay system and some under a full. In each case, estimation includes cohort dummies, kibbutz fixed effects, and the demographic controls gender, father's and mother's education, number of siblings, a set of origin dummies (Africa/Asia, Europe/America, immigrants from FSU, Ethiopia and other countries). Robust standard errors are presented in parentheses. 
Table 8: Controlled Differences in Differences Estimates in Sub-Samples by Gender and Parental Education

\begin{tabular}{ccccc}
\hline \hline & $\begin{array}{c}\text { High School } \\
\text { Completion }\end{array}$ & $\begin{array}{c}\text { Mean } \\
\text { Matriculation } \\
\text { Score }\end{array}$ & $\begin{array}{c}\text { Matriculation } \\
\text { Certification }\end{array}$ & $\begin{array}{c}\text { University } \\
\text { Qualified } \\
\text { Matriculation }\end{array}$ \\
\cline { 2 - 5 } & $(1)$ & $(2)$ & $(3)$ & $(4)$ \\
\hline \hline
\end{tabular}

Experiment of Interest, 10th Grade Students in 1995-1996 and 1999-2000

A. Sample Stratification By Mother's Education

$\begin{array}{ccccc}\text { Low } & 0.049 & 6.175 & 0.116 & 0.100 \\ & (0.024) & (2.553) & (0.053) & (0.053) \\ & \{0.947\} & \{69.03\} & \{0.517\} & \{0.478\} \\ \text { High } & & & & \\ & 0.014 & 0.329 & -0.031 & 0.002 \\ & (0.019) & (2.114) & (0.047) & (0.048) \\ & \{0.965\} & \{74.82\} & \{0.660\} & \{0.625\}\end{array}$

B. Sample Stratification By Father's Education

Low

$\begin{array}{cccc}0.033 & 5.879 & 0.093 & 0.086 \\ (0.027) & (2.781) & (0.055) & (0.055) \\ \{0.943\} & \{68.10\} & \{0.490\} & \{0.447\}\end{array}$

High

$\begin{array}{cccc}0.031 & 1.701 & 0.010 & 0.034 \\ (0.017) & (1.924) & (0.046) & (0.047) \\ \{0.968\} & \{75.43\} & \{0.679\} & \{0.646\}\end{array}$

C. Sample Stratification By Gender

Male

$\begin{array}{cccc}0.052 & 4.820 & 0.060 & 0.056 \\ (0.023) & (2.505) & (0.051) & (0.051) \\ \{0.947\} & \{69.18\} & \{0.535\} & \{0.490\}\end{array}$

Female

$\begin{array}{cccc}0.011 & 2.549 & 0.027 & 0.034 \\ (0.019) & (2.037) & (0.049) & (0.049) \\ \{0.966\} & \{75.16\} & \{0.654\} & \{0.625\}\end{array}$

Notes: This table presents the coefficients of interest in difference-in-differences regressions (equation (2) in the text) comparing students in treatment (reformed 1998-2000) and control (reformed 2003-04) kibbutzim who are treated (10th grade in 1999-2000) and untreated (10th grade in 1995-96), stratified by background characteristics. The dependent variable in column 1 is whether the student completed high school; in column 2 it is her mean score in the matriculation exams; in column 3 it is whether she received a matriculation certificate; in column 4 it is whether she received a matriculation certificate that satisfies the requirements for university study. All regressions include cohort dummies, kibbutz fixed effects, and the demographic controls gender, father's and mother's education, number of siblings, a set of ethnic dummies (origin from Africa/Asia, Europe/America, immigrants from FSU, Ethiopia and other countries). Robust standard errors are presented in parentheses. The means of all outcomes for each sub-group are presented in curly brackets (below the reported standard errors of each parameter). 
Table 9: Controlled Difference in Differences Estimates by Level of Intensity of Exposure to Full Differential Pay, SubSamples by Parental Education

\begin{tabular}{ccccc}
\hline \hline & $\begin{array}{c}\text { Migh School } \\
\text { Completion }\end{array}$ & $\begin{array}{c}\text { Mean } \\
\text { Matriculation } \\
\text { Score }\end{array}$ & $\begin{array}{c}\text { Matriculation } \\
\text { Certification } \\
\text { Qualified } \\
\text { Matriculation }\end{array}$ \\
\cline { 2 - 5 } & $(1)$ & $(2)$ & $(3)$ & $(4)$ \\
\hline
\end{tabular}

\section{A. Sample Stratification by Mother's Education}

Low

Three Years of Full Reform

Three Years of Partial Reform
Three Years of Full Reform

Three Years of Partial Reform

$\begin{array}{cccc}0.044 & 8.255 & 0.196 & 0.168 \\ (0.033) & (3.421) & (0.067) & (0.068) \\ 0.026 & 2.792 & 0.109 & 0.085 \\ (0.033) & (3.612) & (0.069) & (0.069) \\ \{0.943\} & \{68.64\} & \{0.515\} & \{0.476\}\end{array}$

High

$\begin{array}{cccc}0.008 & -0.011 & -0.034 & 0.023 \\ (0.024) & (2.624) & (0.058) & (0.059) \\ 0.006 & -0.246 & -0.047 & -0.036 \\ (0.027) & (2.899) & (0.063) & (0.064) \\ \{0.964\} & \{74.57\} & \{0.656\} & \{0.619\}\end{array}$

\section{B. Sample Stratification by Father's Education}

Low

Three Years of Full Reform

Three Years of Partial Reform

Three Years of Full Reform

Three Years of Partial Reform

$\begin{array}{cccc}0.027 & 9.547 & 0.205 & 0.190 \\ (0.035) & (3.591) & (0.069) & (0.069) \\ & & & \\ 0.025 & 0.996 & -0.015 & -0.035 \\ (0.036) & (3.990) & (0.072) & (0.071) \\ & & & \\ \{0.940\} & \{67.69\} & \{0.484\} & \{0.440\}\end{array}$

High

$\begin{array}{cccc}0.026 & -0.207 & -0.006 & 0.035 \\ (0.024) & (2.508) & (0.057) & (0.058) \\ 0.016 & 2.964 & 0.091 & 0.096 \\ (0.024) & (2.576) & (0.061) & (0.062) \\ \{0.965\} & \{75.19\} & \{0.678\} & \{0.645\}\end{array}$

Notes: This table presents the results of difference-in-differences regressions comparing students in treatment (reformed 1998-2000) and control (reformed 2003-04) kibbutzim who are treated (10th grade in 1999-2000) and untreated (10th grade in 1995-96), where the treatment effect varies by the number of years the student spent in high school under a full relative to partial differential pay system (versions of equation (7) in the text), stratified by mother's (Panel A) or father's (Panel B) education. The regressions omit students who spent some high school years under a partial differential pay system and some under a full. They interact dummies for the number of years each treated student spent in high school under a full differential pay system with the treatment cohort dummy.

Estimation includes cohort dummies, kibbutz fixed effects, and the demographic controls gender, father's and mother's education, number of siblings, a set of origin dummies (Africa/Asia, Europe/America, immigrants from FSU, Ethiopia and other countries). Robust standard errors are presented in parentheses. The means of all outcomes for each sub-group are presented in curly brackets (below the reported standard errors of each parameter). 
Table 10: Controlled Difference in Differences Estimates by Level of Intensity of Exposure to Full Differential Pay, SubSamples by Gender

\begin{tabular}{ccccc}
\hline \hline & $\begin{array}{c}\text { High School } \\
\text { Completion }\end{array}$ & $\begin{array}{c}\text { Mean } \\
\text { Matriculation } \\
\text { Score }\end{array}$ & $\begin{array}{c}\text { Matriculation } \\
\text { Certification }\end{array}$ & $\begin{array}{c}\text { University } \\
\text { Qualified } \\
\text { Matriculation }\end{array}$ \\
\cline { 2 - 6 } & $(1)$ & $(2)$ & $(3)$ & $(4)$ \\
\hline \hline
\end{tabular}

Male

Three Years of Full Reform

Three Years of Partial Reform

$\begin{array}{cccc}0.042 & 6.017 & 0.097 & 0.096 \\ (0.030) & (3.211) & (0.063) & (0.063) \\ & & & \\ 0.018 & 1.085 & 0.028 & 0.007 \\ (0.034) & (3.460) & (0.067) & (0.067) \\ & & & \\ \{0.944\} & \{68.87\} & \{0.532\} & \{0.485\}\end{array}$

Female

Three Years of Full Reform

Three Years of Partial Reform

$$
0.008
$$

0.017

(0.021)

$\{0.965\}$
2.832

(2.710)

2.201

(2.702)

$\{74.83\}$
0.035

(0.062)

0.048

0.045

(0.064)

0.037

(0.064)

$\{0.651\}$

Notes: This table presents the results of difference-in-differences regressions comparing students in treatment (reformed 19982000) and control (reformed 2003-04) kibbutzim who are treated (10th grade in 1999-2000) and untreated (10th grade in 199596), where the treatment effect varies by the number of years the student spent in high school under a full relative to partial differential pay system (versions of equation (7) in the text), stratified by gender. The regressions omit students who spent some high school years under a partial differential pay system and some under a full. They interact dummies for the number of years each treated student spent in high school under a full differential pay system with the treatment cohort dummy.

Estimation includes cohort dummies, kibbutz fixed effects, and the demographic controls gender, father's and mother's education, number of siblings, a set of origin dummies (Africa/Asia, Europe/America, immigrants from FSU, Ethiopia and other countries). Robust standard errors are presented in parentheses. 


\section{ONLINE APPENDIX, NOT FOR PUBLICATION}


Table A1: Wage by Education of All Working Members in One Particular Kibbutz Pre and Post Reform

\begin{tabular}{|c|c|c|c|c|c|c|c|}
\hline & \multirow{2}{*}{\multicolumn{2}{|c|}{ Number of obs }} & \multirow{3}{*}{$\begin{array}{c}\text { Pre reform } \\
\text { Mean/Median Wage } \\
\text { all } \\
\end{array}$} & \multicolumn{4}{|c|}{ Post reform } \\
\hline & & & & \multicolumn{2}{|c|}{ Mean Wage } & \multicolumn{2}{|c|}{ Median Wage } \\
\hline & all & no outliers & & all & no outliers & all & no outliers \\
\hline High school or less & 44 & 37 & 8,661 & 7,980 & 9,331 & 6,929 & 8,000 \\
\hline College or other post-secondary & 36 & 31 & 8,661 & 8,592 & 9,853 & 7,695 & 9,000 \\
\hline MA & 20 & 19 & 8,661 & 10,060 & 10,536 & 9,750 & 10,500 \\
\hline $\mathrm{PhD}$ & 2 & 2 & 8,661 & 10,881 & 10,881 & 10,881 & 10,881 \\
\hline
\end{tabular}

Notes: Wages are measured in New Israeli 2010 Shekels per month. 1 US dollar is currently equal to approximately 3.6 shekels. Outliers are members with wages below 2000 shekels. We exclude them because we suspect they only work part time. 
Table A2: Balancing Tests of Students' Characteristics and Outcomes in Treatment and Control Kibbutzim Treatment:1998-2000, Full Reform. Control: 2003-4

\begin{tabular}{|c|c|c|c|c|c|c|}
\hline & \multicolumn{3}{|c|}{$\begin{array}{l}\text { 10th Grade Students } \\
\text { in } 1995 \text { and } 1996\end{array}$} & \multicolumn{3}{|c|}{$\begin{array}{l}\text { 10th Grade Students } \\
\text { in } 1999 \text { and } 2000\end{array}$} \\
\hline & Treatment & Control & Difference & Treatment & Control & Difference \\
\hline & (1) & (2) & (3) & (4) & (5) & (6) \\
\hline \multicolumn{7}{|l|}{ A. Student's Characteristics } \\
\hline Male & $\begin{array}{c}0.475 \\
(0.500)\end{array}$ & $\begin{array}{c}0.507 \\
(0.500)\end{array}$ & $\begin{array}{l}-0.032 \\
(0.033)\end{array}$ & $\begin{array}{c}0.528 \\
(0.500)\end{array}$ & $\begin{array}{c}0.536 \\
(0.499)\end{array}$ & $\begin{array}{l}-0.008 \\
(0.031)\end{array}$ \\
\hline Father's Years of Schooling & $\begin{array}{l}13.24 \\
(2.938)\end{array}$ & $\begin{array}{c}13.59 \\
(2.841)\end{array}$ & $\begin{array}{l}-0.350 \\
(0.280)\end{array}$ & $\begin{array}{l}13.54 \\
(2.547)\end{array}$ & $\begin{array}{c}14.12 \\
(2.973)\end{array}$ & $\begin{array}{l}-0.583 \\
(0.430)\end{array}$ \\
\hline Mother's Years of Schooling & $\begin{array}{c}13.52 \\
2.34\end{array}$ & $\begin{array}{c}13.71 \\
2.44\end{array}$ & $\begin{array}{l}-0.189 \\
(0.217)\end{array}$ & $\begin{array}{c}14.04 \\
2.21\end{array}$ & $\begin{array}{c}14.08 \\
2.25\end{array}$ & $\begin{array}{l}-0.046 \\
(0.245)\end{array}$ \\
\hline Number of Siblings & $\begin{array}{c}2.60 \\
(1.409)\end{array}$ & $\begin{array}{c}2.65 \\
(1.358)\end{array}$ & $\begin{array}{l}-0.046 \\
(0.231)\end{array}$ & $\begin{array}{c}2.56 \\
(1.332)\end{array}$ & $\begin{array}{c}2.77 \\
(1.581)\end{array}$ & $\begin{array}{l}-0.214 \\
(0.310)\end{array}$ \\
\hline Ethnic Origin: Africa/Asia & $\begin{array}{c}0.098 \\
(0.298)\end{array}$ & $\begin{array}{c}0.103 \\
(0.304)\end{array}$ & $\begin{array}{l}-0.005 \\
(0.020)\end{array}$ & $\begin{array}{c}0.081 \\
(0.272)\end{array}$ & $\begin{array}{c}0.079 \\
(0.270)\end{array}$ & $\begin{array}{c}0.001 \\
(0.022)\end{array}$ \\
\hline Ethnic Origin: Europe/America & $\begin{array}{c}0.359 \\
(0.480)\end{array}$ & $\begin{array}{c}0.379 \\
(0.486)\end{array}$ & $\begin{array}{l}-0.020 \\
(0.043)\end{array}$ & $\begin{array}{c}0.369 \\
(0.483)\end{array}$ & $\begin{array}{c}0.306 \\
(0.461)\end{array}$ & $\begin{array}{c}0.063 \\
(0.040)\end{array}$ \\
\hline Immigrants from Non-FSU Countries & $\begin{array}{c}0.020 \\
(0.140)\end{array}$ & $\begin{array}{c}0.015 \\
(0.122)\end{array}$ & $\begin{array}{c}0.005 \\
(0.008)\end{array}$ & $\begin{array}{c}0.013 \\
(0.112)\end{array}$ & $\begin{array}{c}0.013 \\
(0.114)\end{array}$ & $\begin{array}{l}-0.001 \\
(0.007)\end{array}$ \\
\hline Immigrants from FSU Countries & $\begin{array}{c}0.016 \\
(0.124)\end{array}$ & $\begin{array}{c}0.017 \\
(0.128)\end{array}$ & $\begin{array}{l}-0.001 \\
(0.009)\end{array}$ & $\begin{array}{c}0.032 \\
(0.176)\end{array}$ & $\begin{array}{c}0.023 \\
(0.150)\end{array}$ & $\begin{array}{c}0.009 \\
(0.012)\end{array}$ \\
\hline
\end{tabular}

\section{B. High School Outcomes}

High School Completion

$0.949 \quad 0.967 \quad-0.018$

$(0.221) \quad(0.180) \quad(0.015)$

Mean Matriculation Score

$71.40 \quad 72.48 \quad-1.075$

(21.876) (21.039) (1.573)

Matriculation Certification

$\begin{array}{lll}0.576 & 0.569 & 0.007\end{array}$

$(0.495) \quad(0.496) \quad(0.045)$

University Qualified Matriculation

$0.538 \quad 0.536 \quad 0.002$

$(0.499) \quad(0.499) \quad(0.044)$

Observations

448

601

472

605

Notes: Columns 1, 2, 4 and 5 present means and standard deviations (in parentheses) of characteristics and outcomes of students in treatment and control kibbutzim for affected (1999-2000) and unaffected (1995-1996) cohorts of 10th graders. Columns 3 and 6 present the differences between treatment and control kibbutzim from regression equation (3). Standard errors of these differences clustered at the kibbutz level are given in parentheses. Treatment kibbutzim are those that reformed fully in 1998-2000. Control kibbutzim are those that reformed in 2003-2004. 
Table A3: Balancing Tests of Students' Characteristics and Outcomes in Treatment and Control Kibbutzim Treatment:1998-2000, Partial Reform. Control: 2003-4

\begin{tabular}{|c|c|c|c|c|c|c|}
\hline & \multicolumn{3}{|c|}{$\begin{array}{l}\text { 10th Grade Students } \\
\text { in } 1995 \text { and } 1996\end{array}$} & \multicolumn{3}{|c|}{$\begin{array}{l}\text { 10th Grade Students } \\
\text { in } 1999 \text { and } 2000\end{array}$} \\
\hline & Treatment & Control & Difference & Treatment & Control & Difference \\
\hline & (1) & $(2)$ & (3) & (4) & (5) & (6) \\
\hline \multicolumn{7}{|l|}{ A. Student's Characteristics } \\
\hline Male & $\begin{array}{c}0.508 \\
(0.500)\end{array}$ & $\begin{array}{c}0.507 \\
(0.500)\end{array}$ & $\begin{array}{c}0.000 \\
(0.029)\end{array}$ & $\begin{array}{c}0.520 \\
(0.500)\end{array}$ & $\begin{array}{c}0.536 \\
(0.499)\end{array}$ & $\begin{array}{l}-0.015 \\
(0.025)\end{array}$ \\
\hline Father's Years of Schooling & $\begin{array}{l}13.28 \\
(2.662)\end{array}$ & $\begin{array}{c}13.59 \\
(2.841)\end{array}$ & $\begin{array}{l}-0.313 \\
(0.286)\end{array}$ & $\begin{array}{l}13.65 \\
(2.508)\end{array}$ & $\begin{array}{c}14.12 \\
(2.973)\end{array}$ & $\begin{array}{l}-0.473 \\
(0.429)\end{array}$ \\
\hline Mother's Years of Schooling & $\begin{array}{c}13.35 \\
2.56\end{array}$ & $\begin{array}{c}13.71 \\
2.44\end{array}$ & $\begin{array}{l}-0.363 \\
(0.186)\end{array}$ & $\begin{array}{c}13.86 \\
2.24\end{array}$ & $\begin{array}{c}14.08 \\
2.25\end{array}$ & $\begin{array}{l}-0.218 \\
(0.241)\end{array}$ \\
\hline Number of Siblings & $\begin{array}{c}2.52 \\
(1.320)\end{array}$ & $\begin{array}{c}2.65 \\
(1.358)\end{array}$ & $\begin{array}{l}-0.128 \\
(0.220)\end{array}$ & $\begin{array}{c}2.51 \\
(1.176)\end{array}$ & $\begin{array}{c}2.77 \\
(1.581)\end{array}$ & $\begin{array}{l}-0.259 \\
(0.289)\end{array}$ \\
\hline Ethnic Origin: Africa/Asia & $\begin{array}{c}0.109 \\
(0.312)\end{array}$ & $\begin{array}{c}0.103 \\
(0.304)\end{array}$ & $\begin{array}{c}0.006 \\
(0.018)\end{array}$ & $\begin{array}{c}0.100 \\
(0.300)\end{array}$ & $\begin{array}{c}0.079 \\
(0.270)\end{array}$ & $\begin{array}{c}0.020 \\
(0.025)\end{array}$ \\
\hline Ethnic Origin: Europe/America & $\begin{array}{c}0.337 \\
(0.473)\end{array}$ & $\begin{array}{c}0.379 \\
(0.486)\end{array}$ & $\begin{array}{l}-0.042 \\
(0.039)\end{array}$ & $\begin{array}{c}0.352 \\
(0.478)\end{array}$ & $\begin{array}{c}0.306 \\
(0.461)\end{array}$ & $\begin{array}{c}0.046 \\
(0.038)\end{array}$ \\
\hline Immigrants from Non-FSU Countries & $\begin{array}{c}0.014 \\
(0.117)\end{array}$ & $\begin{array}{c}0.015 \\
(0.122)\end{array}$ & $\begin{array}{l}-0.001 \\
(0.007)\end{array}$ & $\begin{array}{c}0.014 \\
(0.118)\end{array}$ & $\begin{array}{c}0.013 \\
(0.114)\end{array}$ & $\begin{array}{c}0.001 \\
(0.007)\end{array}$ \\
\hline Immigrants from FSU Countries & $\begin{array}{c}0.011 \\
(0.103)\end{array}$ & $\begin{array}{c}0.017 \\
(0.128)\end{array}$ & $\begin{array}{l}-0.006 \\
(0.007)\end{array}$ & $\begin{array}{c}0.030 \\
(0.170)\end{array}$ & $\begin{array}{c}0.023 \\
(0.150)\end{array}$ & $\begin{array}{c}0.007 \\
(0.010)\end{array}$ \\
\hline
\end{tabular}

\section{B. High School Outcomes}

High School Completion

Mean Matriculation Score

Matriculation Certification

University Qualified Matriculation

Observations

$\begin{array}{ccc}0.952 & 0.967 & -0.014 \\ (0.213) & (0.180) & (0.013) \\ & & \\ 70.07 & 72.48 & -2.403 \\ (24.151) & (21.039) & (1.497) \\ & & \\ 0.531 & 0.569 & -0.038 \\ (0.499) & (0.496) & (0.038) \\ & & \\ 0.502 & 0.536 & -0.034 \\ (0.500) & (0.499) & (0.038)\end{array}$

652

601

571

605

Notes: Columns 1, 2, 4 and 5 present means and standard deviations (in parentheses) of characteristics and outcomes of students in treatment and control kibbutzim for affected (1999-2000) and unaffected (1995-1996) cohorts of 10th graders. Columns 3 and 6 present the differences between treatment and control kibbutzim from regression equation (3). Standard errors of these differences clustered at the kibbutz level are given in parentheses. Treatment kibbutzim are those that reformed partially in 1998-2000 (and did not reform fully during the treatment period). Control kibbutzim are those that reformed in 2003-2004. 
Table A4: Balancing Tests of Students' Characteristics and Outcomes in Fully- and Partially-Reformed Kibbutzim

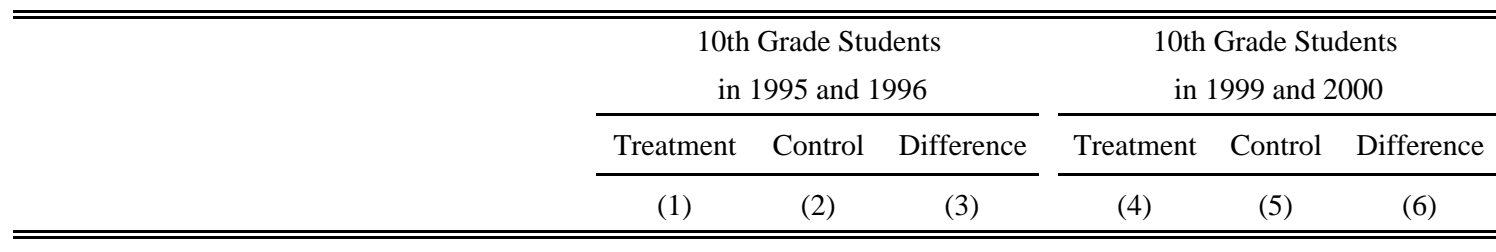

\section{A. Student's Characteristics}

\begin{tabular}{|c|c|c|c|c|c|c|}
\hline Male & $\begin{array}{c}0.475 \\
(0.500)\end{array}$ & $\begin{array}{c}0.508 \\
(0.500)\end{array}$ & $\begin{array}{c}-0.032 \\
(0.029)\end{array}$ & $\begin{array}{c}0.528 \\
(0.500)\end{array}$ & $\begin{array}{c}0.520 \\
(0.500)\end{array}$ & $\begin{array}{c}0.007 \\
(0.032)\end{array}$ \\
\hline Father's Years of Schooling & $\begin{array}{c}13.24 \\
(2.938)\end{array}$ & $\begin{array}{l}13.28 \\
(2.662)\end{array}$ & $\begin{array}{l}-0.037 \\
(0.208)\end{array}$ & $\begin{array}{c}13.54 \\
(2.547)\end{array}$ & $\begin{array}{c}13.65 \\
(2.508)\end{array}$ & $\begin{array}{l}-0.110 \\
(0.185)\end{array}$ \\
\hline Mother's Years of Schooling & $\begin{array}{c}13.52 \\
2.34\end{array}$ & $\begin{array}{c}13.35 \\
2.56\end{array}$ & $\begin{array}{c}0.173 \\
(0.200)\end{array}$ & $\begin{array}{c}14.04 \\
2.21\end{array}$ & $\begin{array}{c}13.86 \\
2.24\end{array}$ & $\begin{array}{c}0.173 \\
(0.159)\end{array}$ \\
\hline Number of Siblings & $\begin{array}{c}2.60 \\
(1.409)\end{array}$ & $\begin{array}{c}2.52 \\
(1.320)\end{array}$ & $\begin{array}{c}0.082 \\
(0.211)\end{array}$ & $\begin{array}{c}2.56 \\
(1.332)\end{array}$ & $\begin{array}{c}2.51 \\
(1.176)\end{array}$ & $\begin{array}{c}0.045 \\
(0.205)\end{array}$ \\
\hline Ethnic Origin: Africa/Asia & $\begin{array}{c}0.098 \\
(0.298)\end{array}$ & $\begin{array}{c}0.109 \\
(0.312)\end{array}$ & $\begin{array}{c}-0.011 \\
(0.021)\end{array}$ & $\begin{array}{c}0.081 \\
(0.272)\end{array}$ & $\begin{array}{c}0.100 \\
(0.300)\end{array}$ & $\begin{array}{l}-0.019 \\
(0.023)\end{array}$ \\
\hline Ethnic Origin: Europe/America & $\begin{array}{c}0.359 \\
(0.480)\end{array}$ & $\begin{array}{c}0.337 \\
(0.473)\end{array}$ & $\begin{array}{c}0.022 \\
(0.042)\end{array}$ & $\begin{array}{c}0.369 \\
(0.483)\end{array}$ & $\begin{array}{c}0.352 \\
(0.478)\end{array}$ & $\begin{array}{c}0.017 \\
(0.040)\end{array}$ \\
\hline Immigrants from non-FSU countries & $\begin{array}{c}0.020 \\
(0.140)\end{array}$ & $\begin{array}{c}0.014 \\
(0.117)\end{array}$ & $\begin{array}{c}0.006 \\
(0.008)\end{array}$ & $\begin{array}{c}0.013 \\
(0.112)\end{array}$ & $\begin{array}{c}0.014 \\
(0.118)\end{array}$ & $\begin{array}{l}-0.001 \\
(0.007)\end{array}$ \\
\hline Immigrants from FSU countries & $\begin{array}{c}0.016 \\
(0.124)\end{array}$ & $\begin{array}{c}0.011 \\
(0.103)\end{array}$ & $\begin{array}{c}0.005 \\
(0.007)\end{array}$ & $\begin{array}{c}0.032 \\
(0.176)\end{array}$ & $\begin{array}{c}0.030 \\
(0.170)\end{array}$ & $\begin{array}{c}0.002 \\
(0.013)\end{array}$ \\
\hline
\end{tabular}

\section{B. High School Outcomes}

High School Completion

$0.949 \quad 0.952 \quad-0.004$

$(0.221) \quad(0.213) \quad(0.015)$

Mean Matriculation Score

$\begin{array}{lll}71.40 \quad 70.07 & 1.328\end{array}$

(21.876) (24.151) (1.622)

Matriculation Certification

$\begin{array}{lll}0.576 & 0.531 & 0.045\end{array}$

$\begin{array}{lll}(0.495) & (0.499) \quad(0.042)\end{array}$

University Qualified Matriculation

$\begin{array}{lll}0.538 & 0.502 & 0.036\end{array}$

$(0.499) \quad(0.500) \quad(0.042)$

Observations

448

652

472

571

Notes: Columns 1, 2, 4 and 5 present means and standard deviations (in parentheses) of characteristics and outcomes of students in treatment and control kibbutzim for affected (1999-2000) and unaffected (1995-1996) cohorts of 10th graders. Columns 3 and 6 present the differences between treatment and control kibbutzim from regression equation (3). Standard errors of these differences clustered at the kibbutz level are given in parentheses. Here "fully reformed kibbutzim" refers to kibbutzim that reformed fully in 1998-2000, and "partially reformed kibbutzim" refers to kibbutzim that reformed partially in 1998-2000 (and didn't fully reform throughout the treatment period). 